Article

\title{
Biological eValuation, DFT Calculations and Molecular Docking Studies on the Antidepressant and Cytotoxicity Activities of Cycas pectinata Buch.-Ham. Compounds
}

\author{
Jinnat Rahman 1,+(D), Abu Montakim Tareq ${ }^{1,+}{ }^{(D)}$, Md. Mohotasin Hossain ${ }^{1}$ (D), \\ Shahenur Alam Sakib ${ }^{\text {(D) }}$, Mohammad Nazmul Islam 1 ${ }^{1 D}$, Md. Hazrat Ali ${ }^{1}$, \\ A. B. M. Neshar Uddin ${ }^{1}{ }^{(D}$, Muminul Hoque ${ }^{1}$, Mst. Samima Nasrin ${ }^{1}\left(\mathbb{D}\right.$, Talha Bin Emran ${ }^{3}$ (D), \\ Raffaele Capasso ${ }^{4, *(\mathbb{D}, \text { A. S. M. Ali Reza }}{ }^{1,5, * \mathbb{D}}$ and Jesus Simal-Gandara ${ }^{6, *(\mathbb{D})}$ \\ 1 Department of Pharmacy, International Islamic University Chittagong, Kumira, \\ Chittagong 4318, Bangladesh; jinnatrahman14@gmail.com (J.R.); montakim0.abu@gmail.com (A.M.T.); \\ mdjisan16@gmail.com (M.M.H.); sayeadiiuc@gmail.com (M.N.I.); hazratpharm@gmail.com (M.H.A.); \\ nesharuddinemon1@gmail.com (A.B.M.N.U.); muminul359@gmail.com (M.H.); \\ shathy_ru@yahoo.com (M.S.N.) \\ 2 Department of Theoretical and Computational Chemistry, University of Dhaka, Dhaka 1000, Bangladesh; \\ sakibhasaniiuc@gmail.com \\ 3 Department of Pharmacy, BGC Trust University Bangladesh, Chittagong 4381, Bangladesh; \\ talhabmb@bgctub.ac.bd \\ 4 Department of Agricultural Sciences, University of Naples Federico II, 80055 Portici, Italy \\ 5 Department of Biochemistry and Molecular Biology, University of Chittagong, Chittagong 4331, Bangladesh \\ 6 Nutrition and Bromatology Group, Department of Analytical and Food Chemistry, Faculty of Food Science \\ and Technology, University of Vigo-Ourense Campus, E32004 Ourense, Spain \\ * Correspondence: rafcapas@unina.it (R.C.); alirezaru@gmail.com (A.S.M.A.R.); jsimal@uvigo.es (J.S.-G.); \\ Tel.: +39-081-678-664 (R.C.); +880-1722-584-336 (A.S.M.A.R.); +34-988-387-000 (J.S.G.) \\ + These authors contributed equally to this work.
}

Received: 9 August 2020; Accepted: 31 August 2020; Published: 3 September 2020

\begin{abstract}
Cycas pectinata Buch.-Ham. is commonly used in folk medicine against various disorders. The present study investigated the antidepressant and cytotoxicity activity of methanol extract of C. pectinata (MECP) along with quantitative phytochemical analysis by GC-MS method. Here, the GC-MS study of MECP presented 41 compounds, among which most were fatty acids, esters, terpenoids and oximes. The antidepressant activity was assessed by the forced swimming test (FST) and tail suspension test (TST) models. In contrast, MECP (200 and $400 \mathrm{mg} / \mathrm{kg}$ ) exhibited a significant and dose-dependent manner reduction in immobility comparable with fluoxetine $(10 \mathrm{mg} / \mathrm{kg})$ and phenelzine $(20 \mathrm{mg} / \mathrm{kg})$. MECP showed a weak toxicity level in the brine shrimp lethality bioassay $\left(E_{50}: 358.65 \mu \mathrm{g} / \mathrm{mL}\right.$ ) comparable to the standard drug vincristine sulfate $\left(\mathrm{ED}_{50}: 2.39 \mu \mathrm{g} / \mathrm{mL}\right.$ ). Three compounds from the GC-MS study were subjected to density functional theory (DFT) calculations, where only cyclopentadecanone oxime showed positive and negative active binding sites. Cyclopentadecanone oxime also showed a good binding interaction in suppressing depression disorders by blocking monoamine oxidase and serotonin receptors with better pharmacokinetic and toxicological properties. Overall, the MECP exhibited a significant antidepressant activity with moderate toxicity, which required further advance studies to identify the mechanism.
\end{abstract}

Keywords: Cycas pectinata; MAO; serotonin; antidepressant; cytotoxicity; oximes; molecular docking; DFT calculations; cyclopentadecanone; oxime 


\section{Introduction}

Depression is a condition characterized by a lowering of the mood and dislike for movement that may distress an individual's thoughts, conduct, emotions, and comfort [1]. Depressive behavior is additionally connected with suicide, which ranges from 10 and 20 million each year [2,3]. According to the World Health Organization (WHO) report, around 450 million people have a mental disorder, which may rise to $15 \%$ by 2020 [4]. In addition, the physical changes additionally happen in extreme, vital, or melancholia or melancholic depression. These comprise sleep deprivation or hypersomnia, modified eating disorders, anorexia and weight reduction and several endocrine dysfunctions with alterations in body temperature. Depressive behavior is the feature of some psychiatric disorders, which may also be caused by somewhat normal life situations; for example, deprivation of sleep, sicknesses, or an adverse effect of drugs and clinical treatments. Patients with major depressive behavior have several symptoms that may reflect in the brain, monoamine synapses or neurotransmitters, explicitly norepinephrine, serotonin, and dopamine [5-7].

There are several antidepressant drugs available to treat depression, but the rate of success of first-line therapy for depression [e.g., selective serotonin reuptake inhibitors (SSRIs) and serotonin-norepinephrine reuptake inhibitors (SNRIs)] is low due to several limitations (adverse effects, lower response and the onset of action, etc.), which have been mentioned in several reviews [8]. Thus, it is imperative that new antidepressant drugs demonstrate improvement of these drawbacks. Several phytochemicals (alkaloids, flavonoids, sterol, terpenes) were reported to have an antidepressant effect [9]. Oximes $\left(\mathrm{R}_{1} \mathrm{R}_{2} \mathrm{C}=\mathrm{NOH}\right)$ are chemicals containing nitrogen produced by organisms in all kingdoms of life [10]. In recent years, oxime derivatives were reported to have several pharmacological activities: cytotoxicity, antibiotic effect, anticonvulsant, antimicrobial, cardiac dysrhythmia, antinociceptive activities [11-14].

Presently monoamine oxidase A (MAO-A) is useful in the treatment of depression disorders, because MAO metabolizes serotonin or 5-hydroxytryptamine (5-HT) in the central nervous system (CNS) [15]. SSRIs are effective in depression, but due to their limitations, the eValuation of new bioactive substances is a major target for the researchers [16]. Oxime derivatives are reported to have an antidepressant effect [17-19], whereas chalcone oxime ethers are reported to have potent inhibitory activity against MAO-B [20]. Our present study design aimed at the eValuation of the biological activity along with a computational study (DFT, molecular docking, ADME/T), where the MAO-A and serotonin receptor are used as a molecular targets for oxime derivatives in depression disorders.

Cycas pectinata Buch.-Ham. (Family: Cycadaceae), commonly known as moniraj or nagmoni, belongs to the genus Cycas [21]. This plant has traditionally been useful for hair growth, curing stomach aches, and curing ulcers [22,23]. Various ethnopharmacological uses in different treatment aspects are documented for Cycas species. Cycas revoluta Thunb. was used for inflammation, vomiting and tonic conditions [24], while Cycas circinalis L. is used for healing wounds and swollen glands. Cycas rumphii Miq. male pollen and cones are reported to have strong narcotic effects [25]. Like in a previous C. pectinata study, a number of fatty acid methyl esters along with other compounds have been reported for C. revolute [26], whereas 16 different bioactive compounds have been reported for C. circinalis [27]. In our previous study, several secondary metabolites from the methanol extract of C. pectinata exhibited the following pharmacological activities, including antioxidant, anti-inflammatory, thrombolytic, anxiolytic, sedative, antinociceptive and antidiarrheal properties [22]. In the present study we report the antidepressant activity along with the cytotoxicity activity of C. pectinate to find a potential lead compound from C. pectinata in alleviating depression disorders by blocking monoamine oxidase (MAOs) and serotonin receptors. To explain this possible mechanism of action of compounds isolated from C. pectinata, we also performed a quantum chemical analysis (DFT calculations) with molecular docking, and ADME/T studies to reveal the potential target(s) for inhibition of the human $\mathrm{MAO}$ and serotonin receptors. 


\section{Results and Discussion}

\subsection{Qualitative and Quantitative Phytochemical Analysis with Acute Toxicity Study}

Phytochemical analysis is useful to eValuate the therapeutic and physiological activities of a plant extract. A qualitative phytochemical screen is performed to determine the presence or absence of secondary plant metabolites. The investigation showed positive results for carbohydrates, alkaloids, phenol, proteins, flavonoids, and saponins (data not shown), which was similar to our previous study that reported similar results [22]. The phytochemical analysis of C. pectinata leaves showed the presence of several phytochemicals. Glycosides are a group of compounds with drug-likeness and numerous studies have suggested that they are a fruitful source of potential drugs. Flavonoids are reported to have anti-inflammatory and anti-cancer activity, whereas tannins possess anti-inflammatory and anti-microbial activity [28]. Phenolic compounds are also present, which possess various physiological functions like anti-aging, anti-inflammation, anti-apoptosis, anti-carcinogenic, inhibition of angiogenesis and enhancement of endothelial function [29].

A total of 66 compounds were identified in the GC-MS analysis, whereas 25 compounds were reported by Tareq et al. [22]. In addition, 41 other compounds are presented in Table 1 and Figure S1, most of which were esters, organic compounds and alcohols. The most abundant compounds along with their retention times were (E)-2-decen-1-ol (20.360), chloroacetic acid 4-pentadecyl ester (20.360), glycerol 1-palmitate (20.009), octadecanoic acid 2-hydroxy-1,3-propanediyl ester (20.009), hexadecanoic acid 2-hydroxy-1-(hydroxymethyl)ethyl ester (20.009), docosanoic acid docosyl ester (19.440), cyclopentadecanone oxime (19.440), and 1-O-(16-hydroxyhexadecyl)-D-mannitol (19.440). These compounds isolated from MECP could help develop a new drug for depression and cancer diseases. The antidepressant activity was eValuated in Swiss albino mice, which required a prior toxicity study. Before starting the experiments and the acute toxicity study of MECP at $400-2000 \mathrm{mg} / \mathrm{kg}$ dose was conducted in Swiss albino mice. The methanol extract of $C$. pectinata leaves was determined to be safe. There was no change of behavioral rush or mortality, morbidity in $8 \mathrm{~h}$ observation period of $400,600,800,1000,2000 \mathrm{mg} / \mathrm{kg}$ of MECP doses which were similar to the previous study [22].

\subsection{Antidepressant Activity}

Anxiety and depression are mental conditions that may recur and are generally undiagnosed and untreated. Physical problems might join these mental conditions, and patients frequently present in medical care centers with physical problems instead of mental situations or problems [30]. Though several antidepressant drugs available, but the rate of success is falling day by day (e.g., SSRIs and SNRIs) $[8,31]$. Thus, the phytochemical study is a topic of interest for the researcher to eValuate a lead compound to treat depression. Several phytochemicals (alkaloids, flavonoids, sterol, terpenes) are reported to have antidepressant effects [9]. Additionally, a few medicinal plants such as $M$. angolensis [32], N. sativa [33] R. rosea [34] are reported to have bilateral anxiolytic and antidepressant effects. In our previous study, MECP showed decreased locomotor activity with a significant anxiolytic activity and also a strong binding affinity against the human serotonin receptor (PDV: 5I6X) suggested by the interacted compounds [22]. Here, the antidepressant activity of MECP was eValuated by a tail suspension test (TST) and forced swimming test (FST), which are the most promising models to assess antidepressant activity. 
Table 1. Quantitative compounds identified from methanol extract of C. pectinata by GC-MS analysis.

\begin{tabular}{|c|c|c|c|c|c|c|c|c|}
\hline S1. No. & RT & Compound Name & $m / z$ & Area & PA (\%) & $\begin{array}{l}\text { Molecular } \\
\text { Formula }\end{array}$ & MW (g/mol) & Class \\
\hline 1 & 5.881 & $\begin{array}{l}\text { 1H-Indole-2,3-dione, 5-chloro-1-(trimethylsilyl)-, } \\
\text { 3-[O-(trimethylsilyl)oxime] }\end{array}$ & 73.00 & 851549 & 3.80 & $\mathrm{C}_{14} \mathrm{H}_{21} \mathrm{ClN}_{2} \mathrm{O}_{2} \mathrm{Si}_{2}$ & 340.95 & Oxime \\
\hline 2 & 11.640 & 3-Octyn-2-ol & 44.00 & 25927 & 0.12 & $\mathrm{C}_{8} \mathrm{H}_{14} \mathrm{O}$ & 126.2 & Fatty alcohol \\
\hline 3 & 11.640 & 2-Cyclohexen-1-one, 3-(3-hydroxybutyl)-2,4,4-trimethyl- & 44.00 & 25927 & 0.12 & $\mathrm{C}_{13} \mathrm{H}_{22} \mathrm{O}_{2}$ & 210.31 & Ketone \\
\hline 4 & 11.640 & Bioallethrin & 44.00 & 25927 & 0.12 & $\mathrm{C}_{19} \mathrm{H}_{26} \mathrm{O}_{3}$ & 302.4 & Pyrethroid \\
\hline 5 & 11.640 & 3-Nonyn-2-ol & 44.00 & 25927 & 0.12 & $\mathrm{C}_{9} \mathrm{H}_{16} \mathrm{O}$ & 140.22 & Secondary alcohol \\
\hline 6 & 12.516 & 1-Octadecyne & 43.00 & 209536 & 0.94 & $\mathrm{C}_{18} \mathrm{H}_{34}$ & 250.5 & Hydrocarbon \\
\hline 7 & 12.516 & Z-2-Dodecenol & 43.00 & 209536 & 0.94 & $\mathrm{C}_{12} \mathrm{H}_{24} \mathrm{O}$ & 184.32 & Fatty alcohol \\
\hline 8 & 12.516 & Phytol, acetate & 43.00 & 209536 & 0.94 & $\mathrm{C}_{22} \mathrm{H}_{42} \mathrm{O}_{2}$ & 338.6 & Diterpene \\
\hline 9 & 12.515 & 5-Nonadecen-1-ol & 81.00 & 122608 & 0.55 & $\mathrm{C}_{19} \mathrm{H}_{38} \mathrm{O}$ & 282.5 & Alcohols \\
\hline 10 & 12.515 & 2-Tridecyne & 81.00 & 122608 & 0.55 & $\mathrm{C}_{13} \mathrm{H}_{24}$ & 180.33 & Alkyne \\
\hline 11 & 12.516 & 9-Eicosyne & 43.00 & 187141 & 0.84 & $\mathrm{C}_{20} \mathrm{H}_{38}$ & 278.5 & Alkyne \\
\hline 12 & 12.516 & Dodecanal & 43.00 & 187141 & 0.84 & $\mathrm{CH}_{3}\left(\mathrm{CH}_{2}\right)_{10} \mathrm{CHO}$ & 184.32 & Aldehyde \\
\hline 13 & 12.516 & trans-2-Dodecen-1-ol, trifluoroacetate & 43.00 & 187141 & 0.84 & $\mathrm{C}_{14} \mathrm{H}_{23} \mathrm{~F}_{3} \mathrm{O}_{2}$ & 280.33 & Ester \\
\hline 14 & 13.450 & Tridecanoic acid, 12-methyl-, methyl ester & 74.00 & 417474 & 1.86 & $\mathrm{C}_{15} \mathrm{H}_{30} \mathrm{O}_{2}$ & 242.4 & Fatty acid \\
\hline 15 & 13.450 & Eicosanoic acid, methyl ester & 74.00 & 417474 & 1.86 & $\mathrm{C}_{21} \mathrm{H}_{42} \mathrm{O}_{2}$ & 326.6 & FAME \\
\hline 16 & 13.450 & Octadecanoic acid, 17-methyl-, methyl ester & 74.00 & 417474 & 1.86 & $\mathrm{C}_{20} \mathrm{H}_{40} \mathrm{O}_{2}$ & 312.5 & FAME \\
\hline 17 & 15.170 & 13-Tetradece-11-yn-1-ol & 67.00 & 47905 & 0.21 & $\mathrm{C}_{14} \mathrm{H}_{24} \mathrm{O}$ & 208.34 & Alcohol \\
\hline 18 & 15.170 & 9,12-Octadecadienoic acid, methyl ester, $(E, E)$ - & 67.00 & 47905 & 0.21 & $\mathrm{C}_{19} \mathrm{H}_{34} \mathrm{O}_{2}$ & 294.5 & FAME \\
\hline 19 & 15.339 & $\begin{array}{l}\text { Cyclopropaneoctanoic acid, 2-[[2-[(2-ethyl- } \\
\text { cyclopropyl)methyl]cyclopropyl]methyl]-, methyl ester }\end{array}$ & 55.00 & 70317 & 0.31 & $\mathrm{C}_{22} \mathrm{H}_{38} \mathrm{O}_{2}$ & 334.5 & Fatty acid \\
\hline 20 & 15.339 & 3-Tetradecyn-1-ol & 55.00 & 70317 & 0.31 & $\mathrm{C}_{14} \mathrm{H}_{26} \mathrm{O}$ & 210.36 & Alkyne \\
\hline 21 & 15.339 & 7-Hexadecenoic acid, methyl ester, (Z)- & 55.00 & 70317 & 0.31 & $\mathrm{C}_{17} \mathrm{H}_{32} \mathrm{O}_{2}$ & 268.4 & Fatty acid \\
\hline 22 & 15.339 & Ethyl iso-allocholate & 55.00 & 70317 & 0.31 & $\mathrm{C}_{26} \mathrm{H}_{44} \mathrm{O}_{5}$ & 436.6 & Steroid \\
\hline 23 & 15.337 & Isophytol, acetate & 71.00 & 172950 & 0.77 & $\mathrm{C}_{22} \mathrm{H}_{42} \mathrm{O}_{2}$ & 338.6 & Diterpene \\
\hline 24 & 15.337 & E-2-Tetradecen-1-ol & 71.00 & 172950 & 0.77 & $\mathrm{C}_{14} \mathrm{H}_{28} \mathrm{O}$ & 212.37 & Alkyne \\
\hline 25 & 15.478 & Tetradecanoic acid, 12-methyl-, methyl ester, (S)- & 74.00 & 107333 & 0.96 & $\mathrm{C}_{16} \mathrm{H}_{32} \mathrm{O}_{2}$ & 316.5 & FAME \\
\hline 26 & 15.478 & Heptacosanoic acid, methyl ester & 74.00 & 107333 & 0.48 & $\mathrm{C}_{28} \mathrm{H}_{56} \mathrm{O}_{2}$ & 424.7 & Fatty acid \\
\hline 27 & 15.478 & Cyclopentanetridecanoic acid, methyl ester & 74.00 & 107333 & 0.48 & $\mathrm{C}_{19} \mathrm{H}_{36} \mathrm{O}_{2}$ & 296.5 & Fatty acid \\
\hline 28 & 16.199 & Dodecanoic acid, 2-(acetyloxy)-1-[(acetyloxy)methyl]ethyl ester & 73.00 & 111054 & 0.49 & $\mathrm{C}_{19} \mathrm{H}_{34} \mathrm{O}_{6}$ & 338.5 & Ester \\
\hline
\end{tabular}


Table 1. Cont.

\begin{tabular}{|c|c|c|c|c|c|c|c|c|}
\hline S1. No. & RT & Compound Name & $m / z$ & Area & PA (\%) & $\begin{array}{c}\text { Molecular } \\
\text { Formula }\end{array}$ & MW (g/mol) & Class \\
\hline 29 & $\begin{array}{c}16.199 \text { and } \\
5.881\end{array}$ & Phloroglucitol & 73.00 & $\begin{array}{c}111054 \text { and } \\
851549\end{array}$ & $\begin{array}{c}0.49 \text { and } \\
3.80\end{array}$ & $\mathrm{C}_{6} \mathrm{H}_{12} \mathrm{O}_{3}$ & 132.16 & Alcohol \\
\hline 30 & 16.604 & Octadecanal, 2-bromo- & 44.00 & 11355 & 0.05 & $\mathrm{C}_{18} \mathrm{H}_{35} \mathrm{BrO}$ & 347.4 & Aldehyde \\
\hline 31 & $\begin{array}{c}16.604 \text { and } \\
12.515\end{array}$ & Undecanal & $\begin{array}{c}81.00 \\
\text { and } \\
44.00\end{array}$ & $\begin{array}{c}122608 \text { and } \\
11355\end{array}$ & $\begin{array}{c}0.05 \text { and } \\
0.55\end{array}$ & $\mathrm{C}_{10} \mathrm{H}_{21} \mathrm{CHO}$ & 170.29 & Aldehyde \\
\hline 32 & 17.623 & Octasiloxane, 1,13,3,3,5,5,7,7,9,9,11,11,13,13,15,15-hexadecamethyl- & 73.00 & 77448 & 0.35 & $\mathrm{C}_{16} \mathrm{H}_{50} \mathrm{O}_{7} \mathrm{Si}_{8}$ & 577.2 & $\begin{array}{l}\text { Volatile organic } \\
\text { compound }\end{array}$ \\
\hline 33 & 17.623 & Dodecanoic acid, 2,3-bis(acetyloxy)propyl ester & 73.00 & 77448 & 0.35 & $\mathrm{C}_{19} \mathrm{H}_{34} \mathrm{O}_{6}$ & 358.5 & Ester \\
\hline 34 & 19.440 & D-Mannitol, 1-O-(16-hydroxyhexadecyl)- & 73.00 & 77215 & 0.34 & $\mathrm{C}_{22} \mathrm{H}_{46} \mathrm{O}_{7}$ & 422.6 & Alcohol \\
\hline 35 & 19.440 & Cyclopentadecanone, oxime & 73.00 & 77215 & 0.34 & $\mathrm{C}_{15} \mathrm{H}_{29} \mathrm{NO}$ & 239.4 & Oxime \\
\hline 36 & 19.440 & Docosanoic acid, docosyl ester & 73.00 & 77215 & 0.34 & $\mathrm{C}_{44} \mathrm{H}_{88} \mathrm{O}_{2}$ & 649.2 & Emollient \\
\hline 37 & 20.009 & Hexadecanoic acid, 2-hydroxy-1-(hydroxymethyl)ethyl ester & 44.00 & 49605 & 0.22 & $\mathrm{C}_{19} \mathrm{H}_{38} \mathrm{O}_{4}$ & 330.5 & $\begin{array}{l}\text { Fatty acid glycerol } \\
\text { ester }\end{array}$ \\
\hline 38 & 20.009 & Octadecanoic acid, 2-hydroxy-1,3-propanediyl ester & 44.00 & 49605 & 0.22 & $\mathrm{C}_{39} \mathrm{H}_{76} \mathrm{O}_{5}$ & 625.0 & Monoalkyl ester \\
\hline 39 & 20.009 & Glycerol 1-palmitate & 44.00 & 49605 & 0.22 & $\mathrm{C}_{19} \mathrm{H}_{38} \mathrm{O}_{4}$ & 330.5 & Fatty acid \\
\hline 40 & 20.360 & Chloroacetic acid, 4-pentadecyl ester & 44.00 & 24894 & 0.11 & $\mathrm{C}_{17} \mathrm{H}_{33} \mathrm{ClO}_{2}$ & 304.9 & Ester \\
\hline 41 & 20.360 & 2-Decen-1-ol, $(E)$ - & 44.00 & 24894 & 0.11 & $\mathrm{C}_{10} \mathrm{H}_{20} \mathrm{O}$ & 156.26 & Fatty acid \\
\hline
\end{tabular}

RT: Retention Time; $m / z$ : $\mathrm{m}$ stands for mass and $\mathrm{z}$ stands for the charge number of ions, PA: Peak Area, MW: Molecular weight; FAME: fatty acid methyl ester. 
Moreover, TST is proposed to have a higher pharmacological sensitivity as compared to FST. In these models, the immobility time or the period of time when animals stopped struggling was calculated, where the antidepressant agents reduce the immobility time in rodents [35]. Fluoxetine is a SSRI very widely used as an antidepressant agent, which basically works by inhibiting access of serotonin transporter protein into presynaptic serotonin neurons by inhibiting the transporter protein and also has mild activity at the 5-hydroxytryptamine 2A (5HT2A) and 5-hydroxytryptamine 2C (5HT2C) receptors [36]. Also, phenelzine was used in this study is a monoamine oxidase inhibitor (MAOI) that acts by inhibiting MAO activity and afterward raises the neural concentration of neurotransmitters, thus increasing monoamine secretion in the synaptic cleft and alleviating depression [37].

In our study, both doses of MECP showed significant antidepressant activity, leading to a possibility that MECP may act in the presynaptic serotonin neurons by inhibiting serotonin transporter protein and by inhibiting the activity of MAO. In TST, 200 and $400 \mathrm{mg} / \mathrm{kg}$ dose exhibited $46.26 \%$ and $51.52 \%$ inhibition in immobility, whereas the standard drugs fluoxetine and phenelzine exhibited $55.06 \%$ and $39.40 \%$, respectively. Additionally, the FST showed significant $(p<0.001)$ immobility, whereas the 200 and $400 \mathrm{mg} / \mathrm{kg}$ exhibited $28.51 \%$ and $32.55 \%$ inhibition of immobility. The results are presented in Figure 1. The presence of alkaloids and saponins in MECP may be a possible reason for this antidepressant activity as well as the presence of oxime derivatives [17-19,38].
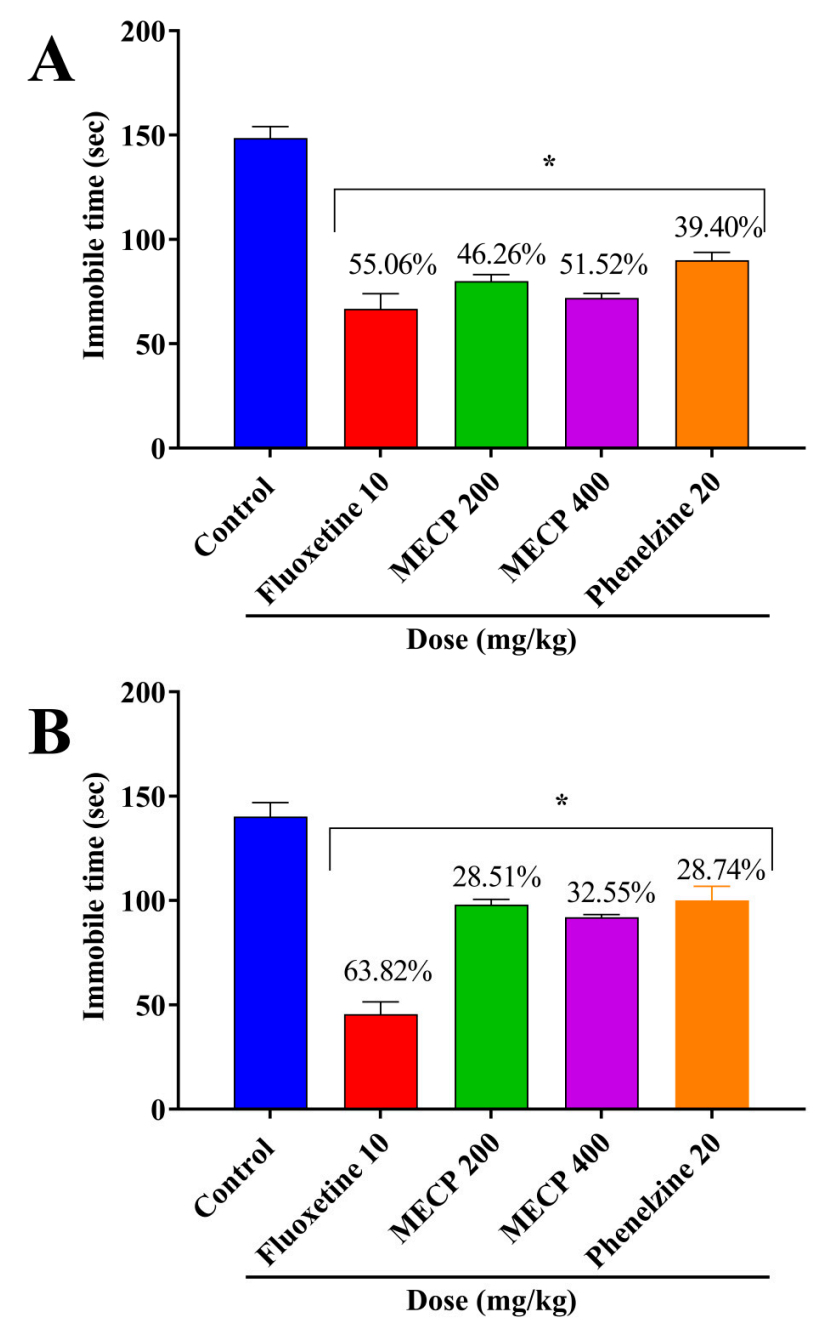

Figure 1. Antidepressant effect of methanol extract of $C$. pectinata leaves (MECP), fluoxetine and phenelzine in tail suspension test (A) and forced swimming test (B). The values are shown as mean \pm standard error of the mean (SEM). ${ }^{*} p<0.001$ statistically significant compared with the control by Dunnett's test $(n=5)$. 


\subsection{Cytotoxicity Activity}

The eValuation of the bioactivity of plant products by the brine shrimp lethality bioassay is an effective, safe and economical method. A good correlation is found in the brine shrimp lethality bioassay with solid human tumors for cytotoxic and pesticidal activity, which is useful for the discovery of active antitumor agents and natural pesticides [39]. This method is also used as a pre-screening test for antitumor research. Generally, the higher the $\mathrm{ED}_{50}$, the lower the toxicity of the extract is and vice versa [40]. In our study, the $\mathrm{ED}_{50}$ of the test samples was calculated using a concentration against the viability of the nauplii. Vincristine sulfate demonstrated the viability of nauplii when the concentration gradually decreased from $10 \mu \mathrm{g} / \mathrm{mL}$ (zero viability) to $0.125 \mu \mathrm{g} / \mathrm{mL}$ ( $90 \%$ viability). MECP has an $\mathrm{ED}_{50}$ of $358.65 \mu \mathrm{g} / \mathrm{mL}$, which is weakly toxic, whereas the standard drug vincristine sulfate exhibited $2.39 \mu \mathrm{g} / \mathrm{mL}$ (highly toxic). The results are presented in Figure 2. This moderate toxicity level of MECP may be due to the presence of oxime derivatives, which reported to have cytotoxicity and antitumor activity $[11,41]$.
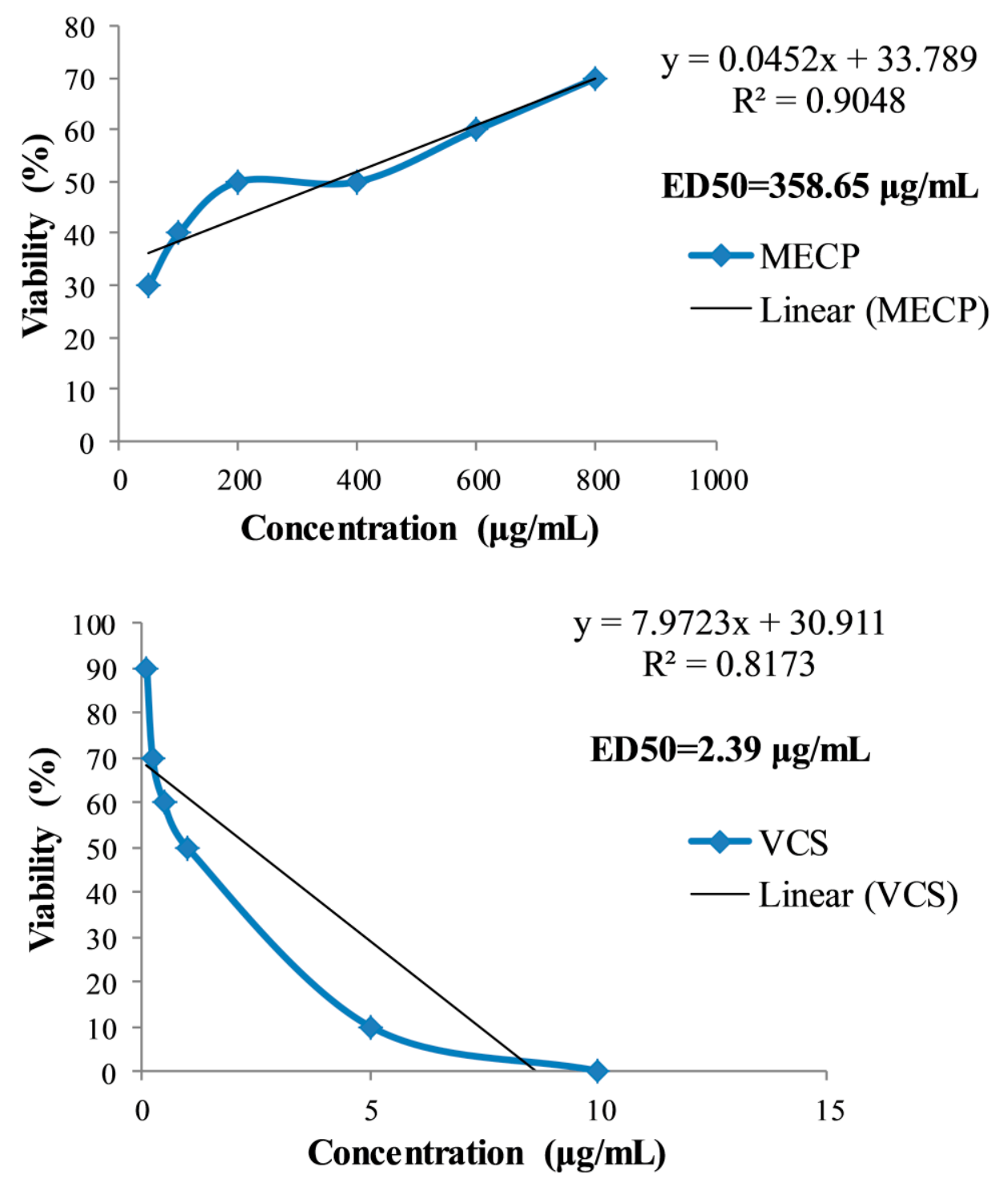

Figure 2. Percentage of mortality of brine shrimp lethality bioassay of methanol extract of C. pectinata leaves (MECP) and standard drug vincristine sulfate (VCS) at different concentrations. 


\subsection{In Silico Study}

\subsubsection{Molecular Geometry}

The sTable configurations of 5-chloro-1-(trimethylsilyl)-1H-indole-2,3-dione 3-[O-(trimethylsilyl)oxime], cyclopentadecanone oxime; and trans-2-dodecen-1-ol trifluoroacetate obtained from the conformational analysis which has been used for reactivity analysis are shown in Figure 3 with the numbering of atoms. From the structural point of view, these three compounds belongs to the $\mathrm{C} 1$ point group symmetry group and hence all the calculated frequencies transform to the same A symmetry species.

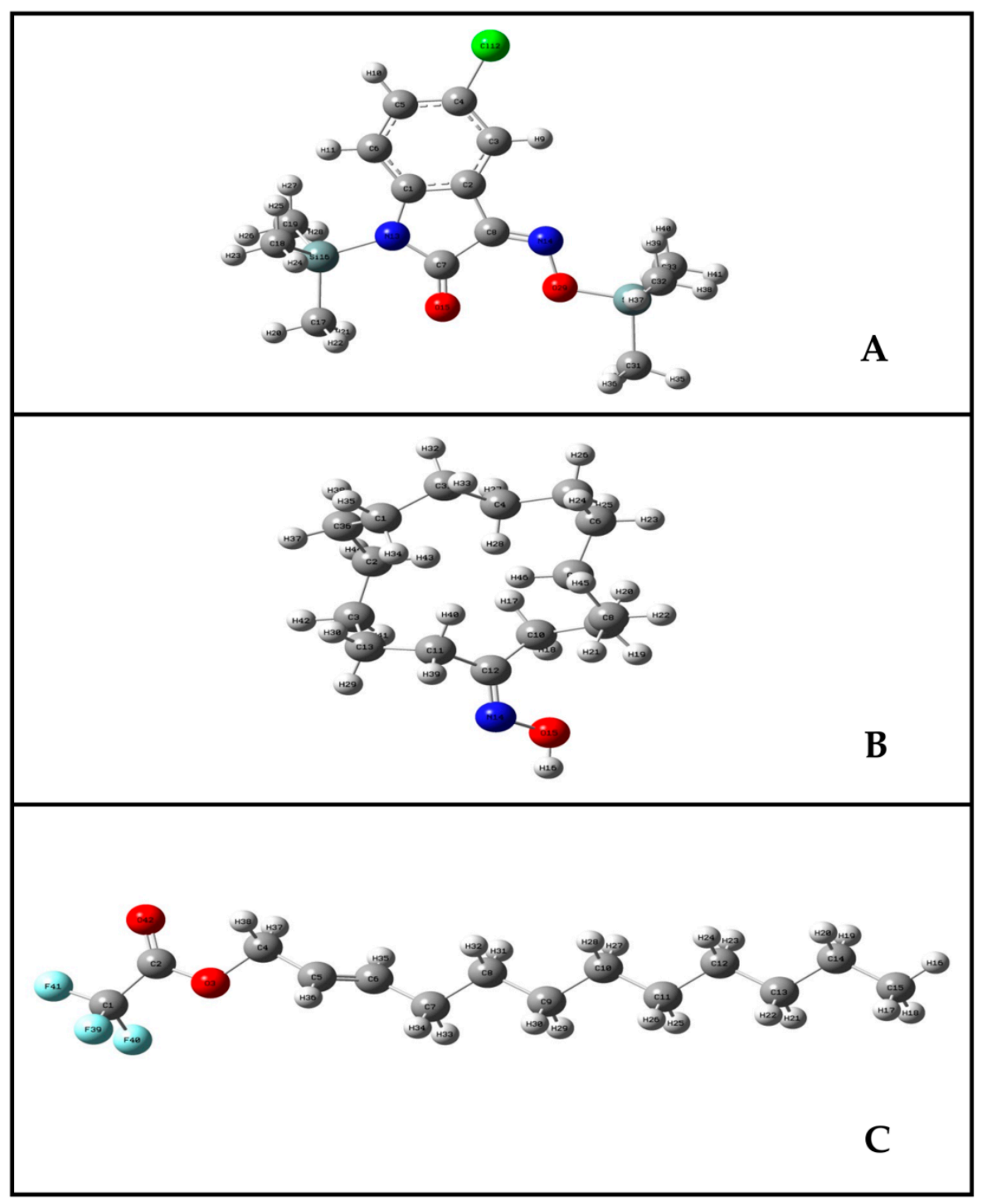

Figure 3. Optimized geometric structures of 5-chloro-1-(trimethylsilyl)-1H-indole-2,3-dione 3-[O(trimethylsilyl)oxime] (A); cyclopentadecanone oxime (B) and trans-2-dodecen-1-ol trifluoroacetate (C).

The total energies of the three compounds calculated by the B3LYP method are -1845.68068 , 718.77081 and -997.04879 Hartree, respectively (Table 2). Among the three compounds trans-2dodecen-1-ol trifluoroacetate showed a higher dipole moment value. Dipole moments tell us about the charge separation in a molecule. The larger the difference in electronegativity of bonded atoms, the larger the dipole moment [42]. Among the three isolated compound, 
5-chloro-1-(trimethylsilyl)-1H-indole-2,3-dione 3-[O-(trimethylsilyl)oxime] has higher polarizability value. Generally, polarizability increases as the volume occupied by electrons increases. In atoms, this occurs because larger atoms have more loosely held electrons than smaller atoms with tightly bound electrons [43].

Table 2. Optimized energies of 5-chloro-1-(trimethylsilyl)-1H-indole-2,3-dione 3-[O-(trimethylsilyl)-oxime]; cyclopentadecanone oxime and trans-2-dodecen-1-ol trifluoroacetate with dipole moment and polarizability.

\begin{tabular}{cccc}
\hline Compounds & Energy (a.u) & Dipole Moment (Debye) & Polarizability (a.u) \\
\hline 5-Chloro-1-(trimethylsilyl)-1H-indole-2,3-dione & -1845.68068 & 1.367 & 261.403 \\
3-[O-(trimethylsilyl)oxime] & -718.77081 & 0.712 & 162.046 \\
Cyclopentadecanone oxime & -997.04879 & 4.968 & 159.682 \\
trans-2-Dodecen-1-ol trifluoroacetate &
\end{tabular}

\subsubsection{Charges and MESP Calculations}

The atomic charges (Mulliken and NBO) play an important role in molecular polarizability, dipole moment, electronic structure, molecular reactivity and a lot of related properties of molecular systems. The charge distributions over the atoms suggest the formation of donor and acceptor pairs involving the charge transferring the molecule. The charges on the atoms of the present 5-chloro-1-(trimethylsilyl)-1H-indole-2,3-dione 3-[O-(trimethylsilyl)oxime]; cyclopentadecanone oxime and trans-2-dodecen-1-ol trifluoroacetate; were calculated by Mulliken population analysis [44] and NBO charges [45] using B3LYP method with 6-31G+ $(d, p)$ basis set, the tabular representation of the results are presented in Tables S1-S3.

For 5-chloro-1-(trimethylsilyl)-1H-indole-2,3-dione 3-[O-(trimethylsilyl)oxime] it can be easily seen that the highest positive Mulliken charge value of 1.710 a.u was accommodated on the $\mathrm{Si}_{16}$ atom that is attached to the pyrrole ring, while in NBO charges the highest positive value was 1.905 a.u on the $\mathrm{Si}_{30}$ atom which connect with $\mathrm{O}$ atom. Also, the Mulliken charge with the highest negative value of $(-0.862 \sim-0.877)$ a.u was on the methyl group $C$ atom wherein NBO charges provide the highest negative value of $(-1.219 \sim-1.225)$ a.u on the methyl group $C$ atom. Due to the electron-withdrawing nature of the methyl group, its $C$ atom is pulling electrons towards it.

As for cyclopentadecanone oxime, it showed the highest positive Mulliken charge value of $0.428 \mathrm{a} . \mathrm{u}$ accommodated on the $\mathrm{H}_{16}$ atom, which is bonded to the $\mathrm{O}$ atom. The highest negative Mulliken charge value of -0.638 a.u belongs to the $\mathrm{O}_{15}$ atom which is attached to the $\mathrm{N}$ atom. The natural atomic charges value is in excellent agreement with the highest positive and negative Mulliken charge values for the same atom of the molecule. From the Table it can be easily seen regarding the Mulliken charge values for trans-2-dodecen-1-ol trifluoroacetate, the highest positive value of 0.769 a.u was accommodated on the $\mathrm{C}_{1}$ atom which is bond with $\mathrm{CF}_{3}$. This natural atomic charge value also agreed with the obtained result for the same carbon. It shows the highest positive value was 0.983 a.u. In Mulliken charges, the highest negative value of -0.480 a.u is accommodated on the $\mathrm{O}_{3}$ atom. This natural atomic charge value does not also agree with the obtained result for the same atom, whereas it shows the highest negative value of -0.524 a.u is accommodated on $\mathrm{O}_{42}$ atom at molecule. From the charges calculation the highest positive and negative value of Mulliken and NBO charge of atoms sometimes did not agreed with each other due to the two methods used.

The molecular electrostatic potential (MESP) surface [46] from Figure 4 illustrates the molecules' charge distributions three-dimensionally. This map allows us to visualize variably charged regions of a molecule. The knowledge of the charge distributions can be used to determine how molecules may interact with one another and it is also used to determine the nature of their chemical bonds [47]. The MESP map was checked out by theoretical calculations using the B3LYP/6-31G+ $(\mathrm{d}, \mathrm{p})$ level. Molecular electrostatic potential shows the electronic density and is useful in recognizing sites for electrophilic attack, nucleophilic reactions, and hydrogen bonding interactions. Different colors represent the different values of the electrostatic potential at the surface. The negative areas (red, orange and yellow 
color) of MESP were related to electrophilic reactivity, the positive areas (blue color) ones to nucleophilic reactivity and green color are neutral regions. This Figure also provides a visual representation of the chemically active sites and the comparative reactivity of atoms. The computed 3D plot of MESP for the title compounds is depicted in the figure, based on the electron density at different points on the molecule. However, potential values of the three isolated compounds ranges from $-6.383 \times 10^{-2}$ a.u (deepest red) to $+6.383 \times 10^{-2}$ a.u (deepest blue), $-5.902 \times 10^{-2}$ a.u (deepest orange) to $+5.902 \times 10^{-2}$ a.u (deepest blue), $-4.638 \times 10^{-2}$ a.u (deepest red) to $+4.638 \times 10^{-2}$ a.u (deepest blue) respectively.

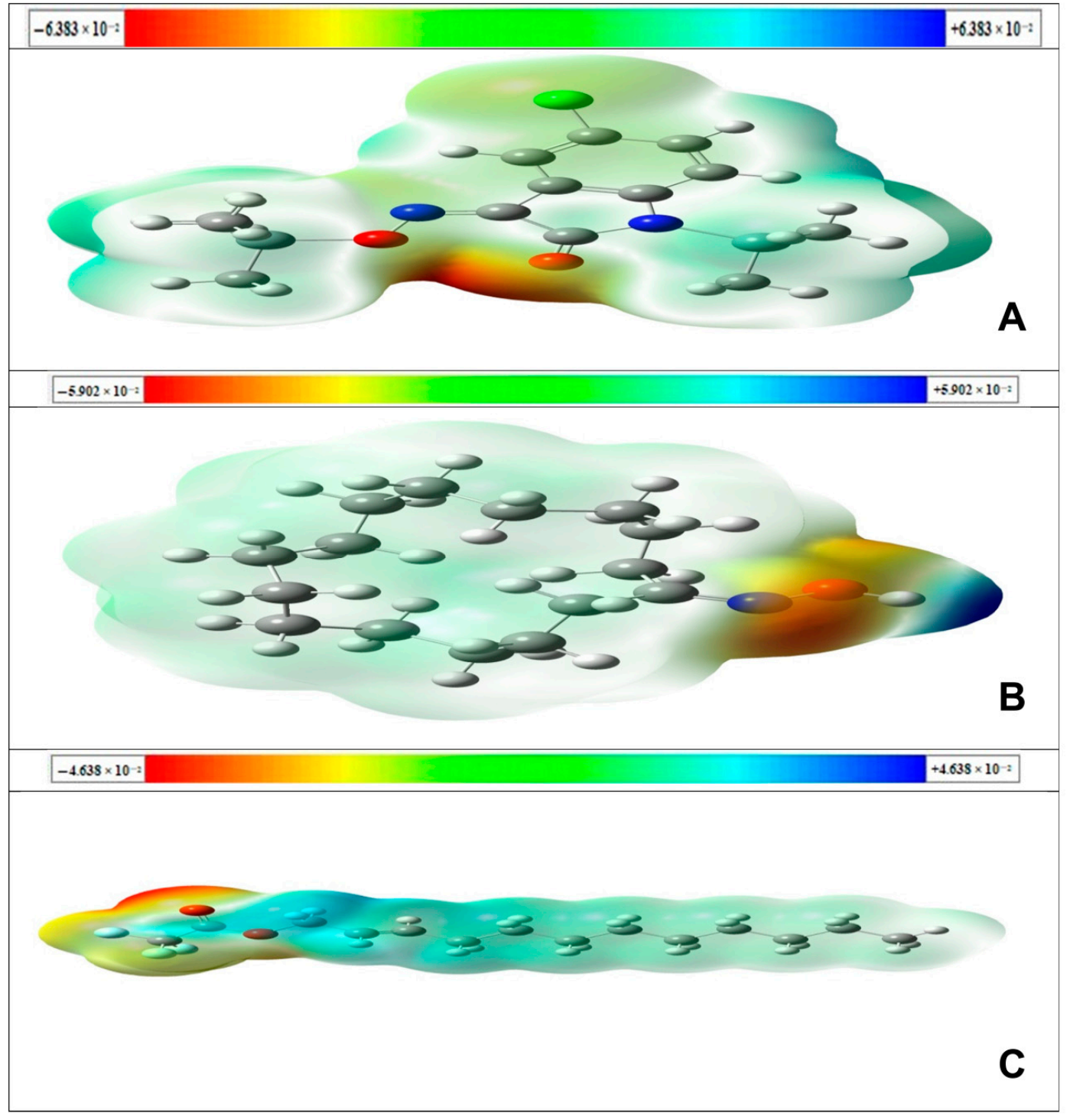

Figure 4. Calculated 3D surface mapped of electrostatic potential for 5-chloro-1-(trimethylsilyl)$1 \mathrm{H}$-indole-2,3-dione 3-[O-(trimethylsilyl)oxime] (A); cyclopentadecanone oxime (B); trans-2-dodecen-1-ol trifluoroacetate (C), respectively in (a.u), the electron density isosurface being 0.0004 (a.u).

According to the MESP map in the Figure for 5-chloro-1-(trimethylsilyl)-1H-indole-2,3-dione 3-[O-(trimethylsilyl)oxime], cyclopentadecanone oxime and trans-2-dodecen-1-ol trifluoroacetate; the negative regions are associated with the $\mathrm{O}_{15}, \mathrm{O}_{15}$, and $\mathrm{O}_{42}$ atoms, respectively. Therefore these atom positions are suiTable sites for electrophilic attack. Alternatively, only cyclopentadecanone oxime showed a positive region associated with the $\mathrm{H}_{16}$ atom that indicates that this atom can be the most probably involved in nucleophilic processes. Here, 5-chloro-1-(trimethylsilyl)-1H-indole-2,3-dione 3-[O-(trimethylsilyl)oxime]; and trans-2-dodecen-1-ol trifluoroacetate; didn't show any nucleophilic 
attack sites. The presence of positive and negative binding sites in cyclopentadecanone oxime may result in good interactions with proteins in biological systems.

\subsubsection{FMOs and Global Descriptors}

The frontier molecular orbitals, HOMO and LUMO, are the most important orbitals in a molecule. They play an important role in the optical and electric properties, as well as in quantum chemistry and the UV-Vis spectra [48]. The highest occupied molecular orbital (HOMO), represents the ionization potential of the molecule and lowest occupied molecular orbital (LUMO), corresponding electron affinity value is called the frontier molecular orbitals (FMOs) showed in Figure 5 were calculated at the B3LYP/6-31G+ $(\mathrm{d}, \mathrm{p})$ level for the three isolated compounds.

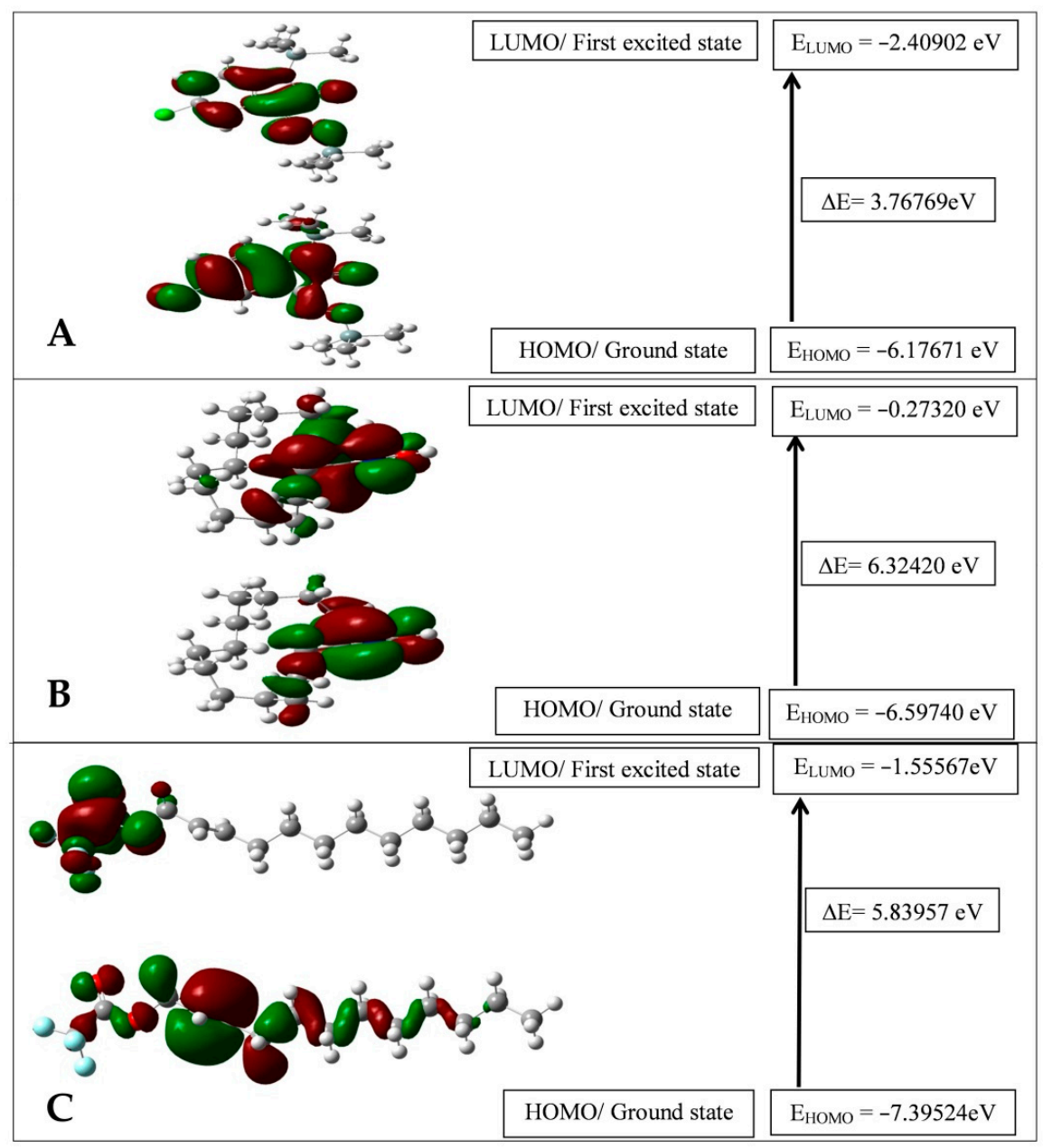

Figure 5. HOMO-LUMO plot 5-chloro-1-(trimethylsilyl)-1H-indole-2,3-dione 3-[O-(trimethylsilyl)-oxime] (A); cyclopentadecanone oxime (B); trans-2-dodecen-1-ol trifluoroacetate (C), respectively, by B3LYP/6-31G+ $(\mathrm{d}, \mathrm{p})$ level of theory.

These orbitals determine the way how the molecule interacts with other species and give information about the reactivity/stability of specific regions of the molecule. The energy of HOMO characterizes the electron-donating ability of a molecule, while LUMO energy determines the ability to accept an electron. Therefore, higher values of $\mathrm{E}_{\mathrm{HOMO}}$ indicate a better tendency towards the donation of an electron. From Figure 5, trans-2-dodecen-1-ol trifluoroacetate is the better molecule which has the ability to accept electrons while the energy value of $\mathrm{HOMO}\left(\mathrm{E}_{\mathrm{HOMO}}=-7.39524 \mathrm{eV}\right)$ that allows it to be the best electron donor molecule. The energy gap between the HOMO and LUMO is very important in determining a molecule's chemical reactivity. A high value of the energy gap indicates that the 
molecule shows high chemical stability; indicates a hard molecule, while a small HOMO-LUMO gap means small excitation energies to the manifold of excited states, and action as a soft molecule. Among three isolated compounds, 5-chloro-1-(trimethylsilyl)- $1 \mathrm{H}$-indole-2,3-dione 3-[O-(trimethylsilyl)oxime] shows the lowest energy gap indicating it is more reactive than the two other compounds.

Using Koopmans' theorem [49,50] (I) and (A) values can be correlated with the frontier orbitals by the relation: $\mathrm{I}=-\mathrm{E}_{\mathrm{HOMO}}$ and $\mathrm{A}=-\mathrm{E}_{\mathrm{LUMO}}$. Ionization potential $(\mathrm{I})$ is defined as the amount of energy needed to remove an electron from a molecule. High ionization energy indicates high stability, chemical inertness and small ionization energy indicating high reactivity of the atoms and molecules. Trans-2-Dodecen-1-ol, trifluoroacetate has the lowest ionization potential value $(\mathrm{I}=7.39524 \mathrm{eV})$, which indicates that it is the best electron donor. The electronic affinity $(A)$ is defined as the energy released when an electron is added to a neutral molecule. A molecule with high (A) values tends to accept electrons easily. From Table 3 it is clear that 5-chloro-1-(trimethylsilyl)-1H-Indole-2,3-dione 3-[O-(trimethylsilyl)oxime] is the most reactive. The global chemical reactivity descriptors such as chemical potential $(\mu)$, electronegativity $(\chi)$, hardness $(\eta)$, softness $(S)$, and electrophilicity index $(\omega)$ which were calculated from the HOMO and LUMO energies were obtained at the level of theory B3LYP/6-31G+ $(d, p)$ and are incorporated in Table 3.

Table 3. Global reactivity descriptors values in the gas phase.

\begin{tabular}{cccc}
\hline $\begin{array}{c}\text { Global Reactivity } \\
\text { Descriptors }\end{array}$ & $\begin{array}{c}\text { 5-Chloro-1-(trimethylsilyl)-1H-indole-2,3-dione } \\
\text { 3-[O-(trimethyl-silyl)oxime] }\end{array}$ & $\begin{array}{c}\text { Cyclopentadecanone } \\
\text { Oxime }\end{array}$ & $\begin{array}{c}\text { trans-2-Dodecen-1-ol } \\
\text { Trifluoroacetate }\end{array}$ \\
\hline Ionisation potential $(\mathrm{I}) \mathrm{eV}$ & 6.17671 & 6.59740 & 7.39524 \\
Electron affinity $(\mathrm{A}) \mathrm{eV}$ & 2.40902 & 0.27320 & 1.55567 \\
Chemical hardness $(\eta)$ & 1.88385 & 3.16210 & 2.91979 \\
Softness $(\mathrm{S})$ & 0.53083 & 0.31625 & 0.34249 \\
Chemical potential $(\mu)$ & -4.29287 & -3.43530 & -4.47546 \\
Electronegativity $(\chi)$ & 4.29287 & 3.43530 & 4.47546 \\
Electrophilicity index $(\omega)$ & 9.21434 & 5.90064 & 10.01485 \\
\hline
\end{tabular}

According to these parameters, the chemical reactivity varies with the structural configuration of the molecules. Global reactivity descriptors such as chemical potential denote as $(\mu=-\chi)$, the absolute electronegativity $(\chi)$ is given by the relation $(\chi=(I P+E A) / 2)$, global hardness and global softness $(S)$ are defined as $\left(\eta=\left(E_{\text {LUMO }}-E_{\text {HOMO }}\right) / 2\right)$ and $(S=1 / 2 \eta)$, the electrophilicity $(\omega)$ can be calculated using the electronic chemical potential and the chemical hardness $\left(\omega=\mu^{2} / 2 \eta\right)$ [51-55]. Hardness $(\eta)$ and softness (S) are useful concepts for understanding the behavior of chemical systems. A hard molecule has a large energy gap and a soft molecule has a small energy gap [56]. Therefore, soft molecules will be more polarizable than hard molecules. From the established theoretical calculations cyclopentadecanone oxime has the highest hardness value $(\eta=3.16210 \mathrm{eV})$, which indicates that it is the hardest molecule. 5-Chloro-1-(trimethylsilyl)-1H-indole-2,3-dione 3-[O-(trimethylsilyl)oxime] has the highest softness $(\mathrm{S}=0.53083 \mathrm{eV})$, so it is the softest molecule. The chemical potential $\mu(\mathrm{eV})$ measures the escaping tendency of an electron and it can be associated with the molecular electronegativity [57] then, as $\mu$ becomes more negative, it is more difficult to lose an electron but easier to gain one. As shown in Table 3, trans-2-dodecen-1-ol trifluoroacetate is the least sTable and the most reactive among all the compounds. Electronegativity $(\chi)$, represents the ability of molecules to attract electrons. The $(\chi)$ values displayed in Table 3 show that cyclopentadecanone oxime; has the higher electronegativity $(4.47546 \mathrm{eV})$ value compared to all the other molecules. Electrophilicity $(\omega)$, that gives an idea of the stabilization energy when the system gets saturated by electrons, which come from the external environment. This reactivity information shows if a molecule is capable of donating charges. A good, more reactive nucleophile is characterized by a lower value of $(\omega)$, while higher values indicate the presence of a good electrophile. Our results indicate that cyclopentadecanone oxime has lower values of $(\omega)$, so that compound is a good nucleophile, whereas trans-2-dodecen-1-ol, trifluoroacetate is a good electrophile. 


\subsubsection{Vibrational Spectral Analysis}

The vibrational band assignments had been performed based on the normal coordinate analysis. Internal coordinates of three isolated compounds had constructed according to Pulay's recommendations [58]. The calculated wavenumbers were selectively scaled according to the scaled quantum mechanical (SQM) method recommended by Rauhut and Pulay [59] using a scale factor with the root mean square (RMS) wavenumber error, which is in the reasonable limit for proper assignment. The observed FT-IR and simulated theoretical spectra calculated at the B3LYP/6-31G+ $(d, p)$ basis set are shown in Figure S2. The calculated wavenumbers and their assignments are also presented in Table 4. The detailed analyses of vibrational wavenumbers for various functional groups are discussed below.

\subsubsection{Hydroxyl (O-H) Group Vibrations}

Bands due to $\mathrm{O}-\mathrm{H}$ stretching are of medium to strong intensity in the infrared spectrum, although it may be broad. For solids, liquids and concentrated solutions a broad band of less intensity is normally observed [60]. The very weak FT-IR band at $3696 \mathrm{~cm}^{-1}$ is assigned to the $\mathrm{O}-\mathrm{H}$ stretching vibrations. Normally free O-H stretching vibrations appeared around $3600 \mathrm{~cm}^{-1}$ for phenols [61]. The observed broad intense IR band for cyclopentadecanone oxime at corresponds to $\mathrm{O}-\mathrm{H}$ stretching mode, which is calculated at $3884 \mathrm{~cm}^{-1}$.

\subsubsection{C-H Vibrations}

Aromatic compounds commonly exhibit multiple weak bands in the $3100-3000 \mathrm{~cm}^{-1}$ region due to aromatic $\mathrm{C}-\mathrm{H}$ stretching vibrations and also in-plane bending vibrations generally lie in the range $1000-1300 \mathrm{~cm}^{-1}$ [62]. The bands appearing at $(3081 \sim 3099) \mathrm{cm}^{-1},(3100 \sim 3200) \mathrm{cm}^{-1},(3023 \sim 3069) \mathrm{cm}^{-1}$ for 5-chloro-1-(trimethylsilyl)-1H-indole-2,3-dione 3-[O-(trimethylsilyl)oxime], cyclopentadecanone oxime and trans-2-dodecen-1-ol trifluoroacetate; respectively in the FT-IR spectrum are assigned to $\mathrm{C}-\mathrm{H}$ ring stretching vibrations. In the present study, the $\mathrm{C}-\mathrm{H}$ in-plane bending vibrations of 5-chloro-1-(trimethylsilyl)-1H-indole-2,3-dione 3-[O-(trimethylsilyl)oxime] and trans-2-dodecen-1-ol trifluoro-acetate is identified at $1137 \mathrm{~cm}^{-1}$ and $989 \mathrm{~cm}^{-1}$ at the B3LYP methods are assigned to $\mathrm{C}-\mathrm{H}$ in-plane bending vibrations.

Table 4. Calculated scaled infra-red (IR) frequencies $\left(\mathrm{cm}^{-1}\right)$ for 5-chloro-1-(trimethylsilyl)-1H-indole-2,3dione 3-[O-(trimethylsilyl)oxime], cyclopentadecanone oxime and trans-2-dodecen-1-ol trifluoroacetate, respectively by DFT B3LYP/6-31+G $(\mathrm{d}, \mathrm{p})$ method (atom positions numbered as in the table).

\begin{tabular}{|c|c|c|c|c|c|}
\hline MD & $\begin{array}{l}\text { 5-Chloro-1-(trimethyl-silyl)- } \\
\text { 1H-indole-2,3-dione } \\
\text { 3-[O-(trimethylsilyl)oxime] }\end{array}$ & MD & $\begin{array}{c}\text { Cyclopentadecanone } \\
\text { Oxime }\end{array}$ & MD & $\begin{array}{l}\text { trans-2-Dodecen-1-ol } \\
\text { Trifluoroacetate }\end{array}$ \\
\hline- & - & $v\left(\mathrm{O}_{15}-\mathrm{H}_{16}\right)$ & 3884 & - & - \\
\hline$v(\mathrm{C}-\mathrm{H})$ & 3081 3099 & $v(\mathrm{C}-\mathrm{H})$ & $3100 \sim 3200$ & $v(\mathrm{C}-\mathrm{H})$ & $3023 \sim 3069$ \\
\hline$v_{\text {Asy }}(\mathrm{H}-\mathrm{C}-\mathrm{H})$ & 2927 3017 & $v_{\text {Asy }}(\mathrm{H}-\mathrm{C}-\mathrm{H})$ & 3051 3093 & $v_{\text {Asy }}(\mathrm{H}-\mathrm{C}-\mathrm{H})$ & 2920 3001 \\
\hline$v_{\mathrm{Sy}}(\mathrm{H}-\mathrm{C}-\mathrm{H})$ & 2916 2919 & $v_{\text {Sy }}(\mathrm{H}-\mathrm{C}-\mathrm{H})$ & 3007 3019 & $v_{S y}(\mathrm{H}-\mathrm{C}-\mathrm{H})$ & $2805 \sim 2917$ \\
\hline- & - & $\delta_{\mathrm{S}}(\mathrm{H}-\mathrm{C}-\mathrm{H})$ & $3023 \sim 3037$ & - & - \\
\hline$v(C=C)_{\text {Aro }}$ & $1555 \sim 1579$ & - & - & $v(\mathrm{C}=\mathrm{C})$ & $1680 \sim 1689$ \\
\hline$v\left(\mathrm{C}_{4}=\mathrm{Cl}_{12}\right)$ & 695 & - & - & $v(C-C)$ & 1283 \\
\hline- & - & $\delta_{S}(\mathrm{H}-\mathrm{C}-\mathrm{H})$ & 1459 1499 & $\delta_{\mathrm{S}}(\mathrm{H}-\mathrm{C}-\mathrm{H})$ & 1407 1506 \\
\hline- & - & $\delta_{\mathrm{W}}(\mathrm{H}-\mathrm{C}-\mathrm{H})$ & $1346 \sim 1373$ & $\delta_{\mathrm{W}}(\mathrm{H}-\mathrm{C}-\mathrm{H})$ & $1324 \sim 1373$ \\
\hline- & - & $\delta_{\mathrm{T}}(\mathrm{H}-\mathrm{C}-\mathrm{H})$ & $1246 \sim 1287$ & $\delta_{\mathrm{T}}(\mathrm{H}-\mathrm{C}-\mathrm{H})$ & $1287 \sim 1312$ \\
\hline$\delta_{W}(\mathrm{C}-\mathrm{H})_{\text {Aro }}$ & 916 & - & - & $\delta(\mathrm{C}-\mathrm{H})$ & 989 \\
\hline$\delta(\mathrm{C}-\mathrm{H})_{\text {Aro }}$ & 1137 & - & - & - & - \\
\hline$v\left(C_{7}=\mathrm{O}_{15}\right)$ & 1717 & - & - & - & - \\
\hline$v\left(C_{18}=N_{14}\right)$ & 1593 & $v\left(\mathrm{C}_{12}=\mathrm{N}_{14}\right)$ & 1759 & - & - \\
\hline$v\left(\mathrm{O}_{29}-\mathrm{N}_{14}\right)$ & $1035 / 979$ & $v\left(\mathrm{O}_{15}-\mathrm{N}_{14}\right)$ & 891 & - & - \\
\hline- & - & $\delta_{\mathrm{S}}\left(\mathrm{C}_{12}-\mathrm{N}_{14}-\mathrm{O}_{15}\right)$ & 524 & - & - \\
\hline- & - & 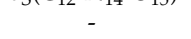 & - & $v(\mathrm{C}-\mathrm{F})$ & $1123 \sim 1169$ \\
\hline
\end{tabular}

Calculated values were corrected by multiplying the frequency factor, $\mathrm{f}=0.964$. MD $=$ Mode of Vibration, $v=$ Stretching,$v_{\mathrm{Sy}}=$ Symmetric Stretching,$v_{\text {Asy }}=$ Asymmetric Stretching,$\delta=$ Bending,$\delta_{\mathrm{S}}=$ Scissoring,$\delta_{\mathrm{W}}=$ Wagging, $\delta_{\mathrm{R}}=$ Rocking, $\delta_{\mathrm{T}}=$ Twisting, $\mathrm{F}^{\mathrm{S}}=$ Scaled frequency, Aro = Aromatic. 


\subsubsection{Methylene (H-C-H) Group Vibrations}

Methyl groups are generally referred to as electron donating substituents in an aromatic ring system. Whenever a methyl group is present in a compound, it gives rise to asymmetric and symmetric stretching vibrations [63]. The asymmetric stretch is usually at a higher wavenumber than the symmetric stretch. The asymmetric stretching vibrations of $\mathrm{CH}_{3}$ are expected in the $2925-3000 \mathrm{~cm}^{-1}$ region and the symmetric $\mathrm{CH}_{3}$ stretching vibrations in the 2905-2940 $\mathrm{cm}^{-1}$ range $[64,65]$. The predicted asymmetric and symmetric stretching vibrations for $\mathrm{CH}_{3}$ are at $(2927 \sim 3017) \mathrm{cm}^{-1}$, (3051 3093) $\mathrm{cm}^{-1}$, (2920 3001) $\mathrm{cm}^{-1}$ and (2916 2919) $\mathrm{cm}^{-1}$, (3007 3019) $\mathrm{cm}^{-1}$, (2805 2917) $\mathrm{cm}^{-1}$ for 5-chloro-1-(trimethylsilyl)-1H-indole-2,3-dione 3-[O-(trimethylsilyl)oxime], cyclopentadecanone oxime and trans-2-dodecen-1-ol trifluoroacetate, respectively. Furthermore, the observed peaks at (1464 1459) $\mathrm{cm}^{-1},\left(1262 \mathrm{~cm}^{-1} \sim 1267\right) \mathrm{cm}^{-1}, 1237 \mathrm{~cm}^{-1}$ can be assigned to the scissoring, twisting and wagging modes of $\mathrm{CH}_{3}$ and $\mathrm{CH}_{2}$ groups in aliphatic chains, respectively [66]. The predicted scissoring, wagging and twisting vibrations for $\mathrm{CH}_{2}$ are at $(1459 \sim 1499) \mathrm{cm}^{-1}$, (1346 1373) $\mathrm{cm}^{-1}$, $(1246 \sim 1287) \mathrm{cm}^{-1}$ and $(1407 \sim 1506) \mathrm{cm}^{-1},(1324 \sim 1373) \mathrm{cm}^{-1},(1287 \sim 1312) \mathrm{cm}^{-11}$ for cyclopentadecanone oxime; and trans-2-dodecen-1-ol trifluoroacetate, respectively.

\subsubsection{C-N Vibrations}

The identification of $\mathrm{C}=\mathrm{N}$ vibrations is a difficult task since mixing of vibrations is possible in this region. Silverstein et al. [67] assigned the $C=N$ stretching absorption in the $1690-1640 \mathrm{~cm}^{-1}$ range for aromatic amines. The present work shows that the theoretically computed value of $\mathrm{C}=\mathrm{N}$ stretching vibrations band observed at $1593 \mathrm{~cm}^{-1}$ and $1759 \mathrm{~cm}^{-1}$ in the FT-IR spectrum for 5-chloro-1-(trimethylsilyl)-1H-indole-2,3-dione 3-[O-(trimethylsilyl)oxime] and cyclopentadecanone oxime, respectively.

\subsection{9. $\mathrm{C}=\mathrm{C}$ Vibrations}

The phenyl ring CC stretching vibrations are generally observed between $1600-1400 \mathrm{~cm}^{-1}$ [68], in which the bands between $1600-1500 \mathrm{~cm}^{-1}$ are assigned to $C=C$ stretching and the rest to C-C stretching, eVen though no such distinction is present within the ring. In the present study, the bands observed at $(1555 \sim 1579) \mathrm{cm}^{-1}$ and $(1680 \sim 1689) \mathrm{cm}^{-1}$ are assigned to $C=C$ for 5-chloro-1-(trimethylsilyl)-1H-indole-2,3-dione 3-[O-(trimethylsilyl)oxime] and trans-2-dodecen-1-ol trifluoroacetate, respectively.

\subsubsection{Carbonyl ( $\mathrm{C}=\mathrm{O})$ Group Vibration}

The $\mathrm{C}=\mathrm{O}$ stretching vibrations give rise to the characteristic bands in IR spectra, and the intensity of these bands can increase owing to the conjugation or formation of hydrogen bonds. The $\mathrm{C}=\mathrm{O}$ stretching of ketones is expected in the region $1760-1730 \mathrm{~cm}^{-1}$ [69]. $\mathrm{C}=\mathrm{O}$ stretching mode is not an independent vibrational mode because of it coupled with the vibrations of adjacent groups. The FT-IR band with strong intensity at $1717 \mathrm{~cm}^{-1}$ alone was assigned to the carbonyl stretching mode of 5-chloro-1-(trimethylsilyl)-1H-indole-2,3-dione 3-[O-(trimethylsilyl)oxime].

\subsubsection{NMR Analysis}

After the optimization of molecular geometry of the three isolated compounds the ${ }^{1} \mathrm{H}$ and ${ }^{13} \mathrm{C}$ nuclear magnetic resonance (NMR) chemical shift values calculated at the B3LYP/6-31G+ $(\mathrm{d}, \mathrm{p})$ level in chloroform solvents by comparing their observed values in $\mathrm{CDCl}_{3}$ solvent with respect to TMS as an internal reference [70]. The theoretically calculated ${ }^{1} \mathrm{H}$ - and ${ }^{13} \mathrm{C}-\mathrm{NMR}$ chemical shift values are presented in Tables 5 and 6. The theoretically determined ${ }^{1} \mathrm{H}$-and ${ }^{13} \mathrm{C}-\mathrm{NMR}$ spectra are shown in Figures S3 and S4, respectively.

The ${ }^{1} \mathrm{H}$ atoms chemical shift values of $1 \mathrm{H}$-Indole-2,3-dione, 5-chloro-1-(trimethylsilyl)-, 3 -[O-(trimethylsilyl)oxime] are divided into two ranges; the first range is approximately $0 \sim 6.5 \mathrm{ppm}$, 
the second range is around $0 \sim-0.956 \mathrm{ppm}$. The first group is due to the $\mathrm{H}$ atoms in the benzene ring and methyl group. The second group is due to the $\mathrm{H}$ atoms in the methyl group attached to $\mathrm{Si}$ atoms. Also, ${ }^{1} \mathrm{H}$ atoms chemical shift values of cyclopentadecanone, oxime divide into two ranges; the first one is around $0 \sim 4.5 \mathrm{ppm}$, the second one is greater than $4.5 \mathrm{ppm}$. The first group is due to the $\mathrm{H}$ atoms in the cyclic alkyl chain and that atoms have slightly positive charges. The highest chemical shift was found for $\mathrm{H}_{16}$ atom which associated with the $\mathrm{O}$ atom. Lastly, the chemical shift values of ${ }^{1} \mathrm{H}$ atoms for trans-2-Dodecen-1-ol, trifluoroacetate are divided into two ranges; the first one is around $0 \sim 5 \mathrm{ppm}$, the second one is greater than $5 \mathrm{ppm}$. Frist range chemical shift values determined those $\mathrm{H}$ atoms in the alkyl chain and showed a slightly positive charge. The highest chemical shifts were found for $\mathrm{H}_{35}, \mathrm{H}_{36}$ atoms which associated with the $\mathrm{C}$ atom nearly $\mathrm{O}$ atom. Due to different chemical atmospheres at various regions around the $\mathrm{H}$ atoms for $1 \mathrm{H}$-Indole-2,3-dione, 5-chloro-1-(trimethylsilyl)-, 3-[O-(trimethylsilyl)oxime]; cyclopentadecanone, oxime; and trans-2-Dodecen-1-ol, trifluoroacetate the chemical shift inequality had originated.

Table 5. Calculated ${ }^{1} \mathrm{H}-\mathrm{NMR}$ isotropic chemical shift (TMS and chloroform solution) by the DFT/B3LYP/6-31G+ $(d, p)$ method (atom positions are numbered in the table).

\begin{tabular}{|c|c|c|c|c|c|}
\hline \multirow[b]{2}{*}{$\begin{array}{l}\text { Proton } \\
\text { No. }\end{array}$} & \multicolumn{5}{|c|}{ Compound (Chemical Shift-ppm) } \\
\hline & $\begin{array}{l}\text { 5-Chloro-1-(trimethylsilyl)- } \\
\text { 1H-indole-2,3-dione } \\
\text { 3-[O- (trimethylsilyl)oxime] }\end{array}$ & $\begin{array}{l}\text { Proton } \\
\text { No. }\end{array}$ & $\begin{array}{c}\text { Cyclopentadecanone } \\
\text { Oxime }\end{array}$ & $\begin{array}{l}\text { Proton } \\
\text { No. }\end{array}$ & $\begin{array}{c}\text { trans-2-Dodecen-1-ol, } \\
\text { Trifluoroacetate }\end{array}$ \\
\hline 9-H & 6.364 & $16-\mathrm{H}$ & 4.643 & $35-\mathrm{H}$ & 5.567 \\
\hline $10-\mathrm{H}$ & 6.129 & $18-\mathrm{H}$ & 2.074 & $36-\mathrm{H}$ & 5.183 \\
\hline $11-\mathrm{H}$ & 5.943 & $40-\mathrm{H}$ & 1.809 & $38-\mathrm{H}$ & 4.266 \\
\hline $22-\mathrm{H}$ & 0.097 & $17-\mathrm{H}$ & 1.221 & $37-\mathrm{H}$ & 3.952 \\
\hline $21-\mathrm{H}$ & 0.078 & 39-H & 1.126 & $33-\mathrm{H}$ & 1.459 \\
\hline $27-\mathrm{H}$ & -0.276 & $28-\mathrm{H}$ & 1.119 & $34-\mathrm{H}$ & 1.319 \\
\hline $25-\mathrm{H}$ & -0.281 & $19-\mathrm{H}$ & 1.068 & $31-\mathrm{H}$ & 0.699 \\
\hline $39-\mathrm{H}$ & -0.364 & $43-\mathrm{H}$ & 0.971 & $30-\mathrm{H}$ & 0.645 \\
\hline $34-\mathrm{H}$ & -0.387 & $46-\mathrm{H}$ & 0.736 & $19-\mathrm{H}$ & 0.611 \\
\hline $40-\mathrm{H}$ & -0.412 & $30-\mathrm{H}$ & 0.705 & $20-\mathrm{H}$ & 0.607 \\
\hline $36-\mathrm{H}$ & -0.420 & $24-\mathrm{H}$ & 0.673 & $28-\mathrm{H}$ & 0.600 \\
\hline 24-H & -0.621 & $27-\mathrm{H}$ & 0.637 & $24-\mathrm{H}$ & 0.596 \\
\hline $28-\mathrm{H}$ & -0.630 & $20-\mathrm{H}$ & 0.587 & $26-\mathrm{H}$ & 0.594 \\
\hline $42-\mathrm{H}$ & -0.743 & $25-\mathrm{H}$ & 0.574 & $23-\mathrm{H}$ & 0.593 \\
\hline $37-\mathrm{H}$ & -0.759 & $34-\mathrm{H}$ & 0.570 & $27-\mathrm{H}$ & 0.592 \\
\hline $23-\mathrm{H}$ & -0.848 & $29-\mathrm{H}$ & 0.524 & $22-\mathrm{H}$ & 0.582 \\
\hline $26-\mathrm{H}$ & -0.851 & $37-\mathrm{H}$ & 0.520 & $29-\mathrm{H}$ & 0.579 \\
\hline $35-\mathrm{H}$ & -0.904 & $41-\mathrm{H}$ & 0.508 & $21-\mathrm{H}$ & 0.579 \\
\hline $20-\mathrm{H}$ & -0.918 & $33-\mathrm{H}$ & 0.505 & $25-\mathrm{H}$ & 0.579 \\
\hline $41-\mathrm{H}$ & -0.948 & $38-\mathrm{H}$ & 0.505 & $32-\mathrm{H}$ & 0.503 \\
\hline \multirow[t]{9}{*}{$38-\mathrm{H}$} & -0.956 & $21-\mathrm{H}$ & 0.478 & $16-\mathrm{H}$ & 0.245 \\
\hline & & $35-\mathrm{H}$ & 0.395 & $18-\mathrm{H}$ & 0.131 \\
\hline & & $22-\mathrm{H}$ & 0.354 & $17-\mathrm{H}$ & 0.124 \\
\hline & & $44-\mathrm{H}$ & 0.316 & & \\
\hline & & $42-\mathrm{H}$ & 0.298 & & \\
\hline & & $23-\mathrm{H}$ & 0.256 & & \\
\hline & & $32-\mathrm{H}$ & 0.252 & & \\
\hline & & $45-\mathrm{H}$ & 0.248 & & \\
\hline & & $26-\mathrm{H}$ & 0.181 & & \\
\hline
\end{tabular}

The calculated ${ }^{13} \mathrm{C}$ chemical shift values of for 5-chloro-1-(trimethylsilyl)-1H-indole-2,3-dione 3-[O-(trimethylsilyl)oxime] are in the $-15 \sim 143 \mathrm{ppm}$ range. This range is divided into two parts; the first range is greater than $100 \mathrm{ppm}$ for $\mathrm{C}_{7}, \mathrm{C}_{8}, \mathrm{C}_{1}, \mathrm{C}_{4}, \mathrm{C}_{5}, \mathrm{C}_{2}, \mathrm{C}_{3}$ atoms which are located in the benzene ring. The second range is less than 100 ppm for $C_{6}, C_{17}, C_{33}, C_{19}, C_{18}, C_{32}, C_{31}$ atoms that alkyl chain carbons attached to silicon atoms. Also, the ${ }^{13} \mathrm{C}$ chemical shift values of cyclopentadecanone oxime are in the 11 147 ppm range. This range divided into two part; firstly $146.55 \mathrm{ppm}$ was found for $\mathrm{O}$ bonded $\mathrm{C}_{12}$ atom and below $100 \mathrm{ppm}$ corresponds to the $\mathrm{C}_{11}, \mathrm{C}_{10}, \mathrm{C}_{8}, \mathrm{C}_{36}, \mathrm{C}_{1}, \mathrm{C}_{13}, \mathrm{C}_{3}, \mathrm{C}_{4}, \mathrm{C}_{31}, \mathrm{C}_{5}, \mathrm{C}_{6}$, $\mathrm{C}_{7}, \mathrm{C}_{2}, \mathrm{C}_{9}$ atoms in the cyclic alkyl chain. Finally, the trans-2-dodecen-1-ol trifluoroacetate chemical shift values are found in the $3 \sim 152 \mathrm{ppm}$ range. The highest chemical shift values were found at 151.74, 
$129.32,121.59$ and $105.65 \mathrm{ppm}$ for the $\mathrm{C}_{2}, \mathrm{C}_{6}, \mathrm{C}_{1}$, and $\mathrm{C}_{5}$ atoms that are bonded with a highly negative charge $\mathrm{O}$ atom. Besides, less than $100 \mathrm{ppm}$ values are found for the $\mathrm{C}_{4}, \mathrm{C}_{7}, \mathrm{C}_{13}, \mathrm{C}_{12}, \mathrm{C}_{11}, \mathrm{C}_{10}, \mathrm{C}_{9}, \mathrm{C}_{8}$, $\mathrm{C}_{14}$ and $\mathrm{C}_{15}$ atoms that are located in the straight alkyl chain.

Table 6. Calculated ${ }^{13} \mathrm{C}-\mathrm{NMR}$ isotropic chemical shift (TMS and chloroform solution) by the $\mathrm{DFT} / \mathrm{B} 3 \mathrm{LYP} / 6-31 \mathrm{G}+(\mathrm{d}, \mathrm{p})$ method (atom positions numbered in the table).

\begin{tabular}{|c|c|c|c|c|c|}
\hline \multirow[b]{2}{*}{$\begin{array}{l}\text { Carbon } \\
\text { No. }\end{array}$} & \multicolumn{5}{|c|}{ Compound (Chemical Shift-ppm) } \\
\hline & $\begin{array}{c}\text { 5-Chloro-1-(trimethylsilyl)- } \\
1 H \text {-indole-2,3-dione } \\
\text { 3-[O-(trimethylsilyl)oxime] }\end{array}$ & $\begin{array}{l}\text { Carbon } \\
\text { No. }\end{array}$ & $\begin{array}{c}\text { Cyclopentadecanone } \\
\text { Oxime }\end{array}$ & $\begin{array}{l}\text { Carbon } \\
\text { No. }\end{array}$ & $\begin{array}{l}\text { trans-2-Dodecen-1-ol } \\
\text { Trifluoroacetate }\end{array}$ \\
\hline $7-\mathrm{C}$ & 142.311 & $12-\mathrm{C}$ & 146.455 & $2-\mathrm{C}$ & 151.741 \\
\hline $8-\mathrm{C}$ & 133.869 & $11-C$ & 21.760 & $6-C$ & 129.323 \\
\hline $1-\mathrm{C}$ & 128.589 & $10-\mathrm{C}$ & 16.876 & $1-\mathrm{C}$ & 121.591 \\
\hline $4-\mathrm{C}$ & 120.975 & $8-\mathrm{C}$ & 15.603 & $5-\mathrm{C}$ & 105.659 \\
\hline $5-\mathrm{C}$ & 113.284 & $36-\mathrm{C}$ & 15.499 & $4-\mathrm{C}$ & 63.818 \\
\hline $2-\mathrm{C}$ & 108.036 & $1-\mathrm{C}$ & 15.387 & $7-\mathrm{C}$ & 24.997 \\
\hline $3-C$ & 103.793 & $13-\mathrm{C}$ & 15.320 & $13-\mathrm{C}$ & 23.385 \\
\hline $6-C$ & 96.637 & $3-C$ & 14.511 & $12-\mathrm{C}$ & 22.139 \\
\hline $17-C$ & -12.527 & $4-C$ & 14.094 & $11-\mathrm{C}$ & 22.046 \\
\hline $33-C$ & -13.724 & $31-C$ & 13.771 & $10-C$ & 21.930 \\
\hline $19-\mathrm{C}$ & -13.895 & $5-\mathrm{C}$ & 13.444 & $9-\mathrm{C}$ & 21.861 \\
\hline $18-\mathrm{C}$ & -13.914 & $6-C$ & 13.024 & $8-\mathrm{C}$ & 21.102 \\
\hline $32-\mathrm{C}$ & -13.918 & $7-\mathrm{C}$ & 12.407 & $14-\mathrm{C}$ & 14.600 \\
\hline \multirow[t]{2}{*}{$31-\mathrm{C}$} & -14.110 & $2-\mathrm{C}$ & 11.635 & $15-\mathrm{C}$ & 3.962 \\
\hline & & $9-\mathrm{C}$ & 11.045 & & \\
\hline
\end{tabular}

\subsubsection{Molecular Docking Study}

Computer-aided drug design (CADD) plays a significant role in developing new drugs. There are mainly two types of drug design methods available, namely: structure-based and ligand-based drug design [71]. In our previous study, we used ligand-based interactions to select a lead compound with sedative activity, which exhibited a significant binding affinity towards the human serotonin receptor (PDB: 5I6X) [22]. Here, the MAO receptor is used because MAO-A is generally targeted to treat depression and anxiety, whereas MAO-B useful for Alzheimer's disease (AD) and Parkinson's disease [72]. As oxime derivatives were reported to have antidepressant effects [17-19], in our present study, human monoamine oxidase A (PDB: 2Z5X) was used for a molecular docking study of antidepressant activity. The antidepressant activity is presented in Table 7 . In the present study, cyclopentadecanone oxime and trans-2-dodecen-1-ol trifluoroacetate showed the highest and lowermost binding affinity against human monoamine oxidase A (PDB: 2Z5X), with docking scores of $-4.333 \mathrm{kcal} / \mathrm{mol}$ and $-3.155 \mathrm{kcal} / \mathrm{mol}$, respectively. 5-Chloro-1-(trimethylsilyl)- $1 \mathrm{H}$-indole-2,3-dione 3-[O-(trimethylsilyl)oxime] did not show any interaction, whereas the standard drug phenelzine showed $-5.324 \mathrm{kcal} / \mathrm{mol}$ binding affinity. Cyclopentadecanone oxime interacted with the monoamine oxidase A (PDB: 2Z5X) by one $\pi$-alkyl interaction to Phe 112. The interaction of the compounds is presented in Figure S5.

Human serotonin receptor (PDB: 5I6X) used also for the molecular docking study, where cyclopentadecanone oxime and trans-2-dodecen-1-ol trifluoroacetate exhibited the highest and lowermost binding affinity, with docking scores of $-6.537 \mathrm{kcal} / \mathrm{mol}$ and $-2.387 \mathrm{kcal} / \mathrm{mol}$, respectively The standard drug fluoxetine shows a $-9.07 \mathrm{kcal} / \mathrm{mol}$ interaction. Cyclopentadecanone oxime interacted with the human serotonin receptor (PDB: 5I6X) by one H-bond to Asp 98 and one alkyl interaction to Ile 172. The interaction of the compounds is presented in Figure S6. 
Table 7. Docking scores of the identified compounds from methanol extract of C. pectinata leaves.

\begin{tabular}{lcccc}
\hline \multirow{2}{*}{ Compounds } & \multicolumn{3}{c}{ Docking Score (kcal/mol) } \\
\cline { 2 - 5 } & 2Z5X & 5I6X & 1ERR & 1M17 \\
\hline 5-Chloro-1-(trimethylsilyl)-1H-indole-2,3-dione & - & - & - & - \\
3-[O-(trimethyl- silyl)oxime] & & & & -4.59 \\
Cyclopentadecanone oxime & -4.333 & -6.537 & -7.685 & -4.59 \\
trans-2-Dodecen-1-ol trifluoroacetate & -3.155 & -2.387 & -1.857 & -2.674 \\
Standard drugs (Phenelzine/Fluoxetine/Vincristine sulfate) & -5.324 & -9.07 & -3.896 & -3.85 \\
\hline
\end{tabular}

The molecular docking study of cytotoxicity activity was performed against the human estrogen receptor (PDB ID: 1ERR) and epidermal growth factor receptor tyrosine kinase (PDB ID: 1M17). Cyclopentadecanone oxime gave a $-7.685 \mathrm{kcal} / \mathrm{mol}$ and $-4.59 \mathrm{kcal} / \mathrm{mol}$ binding interaction against the human estrogen receptor (PDB ID: 1ERR) and epidermal growth factor receptor tyrosine kinase (PDB ID: 1M17), whereas the standard drug vincristine sulfate exhibited $-3.896 \mathrm{kcal} / \mathrm{mol}$ and $-3.85 \mathrm{kcal} / \mathrm{mol}$ interactions, respectively. Cyclopentadecanone oxime interacted with the human estrogen receptor (PDB: 1ERR) through one H-bond to Glu 353, one $\pi$-alkyl interaction to Phe 404 and an alkyl-interaction to Leu 346. In addition cyclopentadecanone oxime interacted with the epidermal growth factor receptor tyrosine kinase (PDB ID: 1M17) through one H-bond to Met 769, and two alkyl-interactions to Val 702 and Leu 820. The interactions of the compounds are presented in Figures S7 and S8.

\subsubsection{ADME/T and Toxicological Properties Analysis}

ADME properties and drug toxicity are important in preventing the early introduction of drugs into the commercial market. From a business point of view, it is necessary to remove the poor pharmacokinetic profile compounds, which reduces the cost of the drug development stage. As a result, over the previous decade, ADME/T screening has been applied in the early drug discovery phase [73]. The selected isolated compounds from the methanol extract of $C$. pectinata were subjected to the ADME/T profiling by following Lipinski's (Rule of Five) [74] and Veber's rules [75]. The three compounds 5-chloro-1-(trimethylsilyl)- $1 \mathrm{H}$-indole-2,3-dione 3-[O-(trimethylsilyl) oxime]; cyclopentadecanone oxime; and trans-2-dodecen-1-ol trifluoroacetate satisfy Lipinski's Rule of Five, whereas trans-2-dodecen-1-ol trifluoroacetate violated Veber's rules (Table 8).

Table 8. ADME/T properties of the selected compounds in MECP by SwissADME.

\begin{tabular}{cccccccc}
\hline Compounds & \multicolumn{3}{c}{ Lipinski Rules } & Lipinski & \multicolumn{2}{c}{ Veber Rules } \\
\cline { 2 - 4 } & MW & HBA & HBD & Log P & Violations & nRB & TPSA \\
\hline 5-Chloro-1-(trimethylsilyl)-1H-indole-2,3-dione & 340.95 & 3 & 0 & 2.38 & 0 & 3 & 41.90 \\
3-[O-(trimethylsilyl)oxime] & 239.40 & 2 & 1 & 3.55 & 0 & 0 & 32.59 \\
$\begin{array}{c}\text { Cyclopentadecanone oxime } \\
\text { trans-2-Dodecen-1-ol trifluoroacetate }\end{array}$ & 280.33 & 5 & 0 & 3.96 & 0 & 12 & 26.30 \\
\hline
\end{tabular}

MW, Molecular weight (<500 g/mol); HBA, Hydrogen bond acceptor (<10); HBD, Hydrogen bond donor (<5); Log P,

Lipophilicity ( $\leq 5)$; nRB: number of rotaTable bond $(\leq 10)$; TPSA: topological polar surface area $\left(\leq 140 \AA^{2}\right)$.

In the toxicological study, 5-chloro-1-(trimethylsilyl)-1H-indole-2,3-dione 3-[O-(trimethylsilyl)-oxime] did not exhibit any risk of toxicity, whereas cyclopentadecanone oxime and trans-2-dodecen-1-ol trifluoroacetate showed risks of Ames toxicity and carcinogenic effect, respectively (Table 9). Aside from these effects, all three compounds can be considered as lead compounds with antidepressant and cytotoxicity activity. 
Table 9. Toxicological properties of the selected compounds in MECP.

\begin{tabular}{cccc}
\hline \multirow{2}{*}{ Parameters } & \multicolumn{3}{c}{ Compounds } \\
\cline { 2 - 4 } & $\begin{array}{c}\text { 5-Chloro-1-(trimethylsilyl)-1H-Indole- } \\
\text { 2,3-dione 3-[O-(trimethylsilyl)oxime] }\end{array}$ & $\begin{array}{c}\text { Cyclopentadecanone } \\
\text { Oxime }\end{array}$ & $\begin{array}{c}\text { trans-2-Dodecen-1-ol } \\
\text { Trifluoroacetate }\end{array}$ \\
\hline Ames toxicity & NAT & AT & NAT \\
Carcinogens & NC & NC & C \\
Acute oral toxicity & III & III & III \\
Rat acute toxicity & 2.6849 & 2.1203 & 2.6831 \\
\hline
\end{tabular}

NAT, Non-Ames toxic; AT, Ames toxic; NC, Non-carcinogenic; C, carcinogenic; NR, Non-required. Category-I means $\left(\mathrm{LD}_{50} \leq 50 \mathrm{mg} / \mathrm{kg}\right)$ and Category-III $\left(500 \mathrm{mg} / \mathrm{kg}>\mathrm{LD}_{50}<5000 \mathrm{mg} / \mathrm{kg}\right)$.

\section{Materials and Methods}

\subsection{Chemicals}

Fluoxetine (Square Pharmaceuticals Ltd., Dhaka, Bangladesh), phenelzine (Ranbaxy Laboratories, Haryana, India), Tween-80 (Sigma Aldrich Co., St. Louis, MO, USA), and vincristine sulfate ( $2 \mathrm{mg} / \mathrm{vial}$ ) (Beacon Pharmaceuticals Ltd. Dhaka, Bangladesh) were purchased from a local trader. All other chemicals were analytical grade.

\subsection{Plant Materials and Preparation of Crude Extract}

The details of the C. pectinata leaves (MECP) plant material were described in our earlier study [22]. The freshly collected leaves were ground into a coarse powder using a grinder (NOWAKE, Hokuto, Japan). The maceration of powder and methanol solvent was followed in a 1:4 ratio, with filtration by Whatman filter paper (\#1) after seven days. The filtration was followed by eVaporation in a water bath $\left(40^{\circ} \mathrm{C}\right)$ to obtain a crude extract. The crude extract was kept under refrigeration at $4{ }^{\circ} \mathrm{C}$ until further use.

\subsection{Experimental Animals}

The average weight of 25-35 g of six-seven weeks old Swiss albino mice of both sexes was obtained from the animal house of Department of Pharmacy, International Islamic University of Chittagong (IIUC), Chittagong, Bangladesh. The animals were adapted with the laboratory condition (room temperature $25 \pm 2{ }^{\circ} \mathrm{C}$, relative humidity $55-60 \%$ ) by supplying food pellets and water. For the use of the experiment, all the animals were adapted for 14 days with laboratory conditions. The study was approved by the Institutional Animal Ethical Committee, Department of Pharmacy, International Islamic University Chittagong, Bangladesh, according to governmental guidelines under the reference (Pharm/p\&d/138/13-'19,22/12/2019) [76].

\subsection{GC-MS (Gas Chromatography-Mass Spectroscopy) Analysis of MECP}

The detailed gas chromatography-mass spectroscopy (GC-MS) analysis of the methanol extract of C. pectinata leaves (MECP) were described in the earlier study of Tareq et al. [22].

\subsection{Acute Toxicity Study}

The acute oral toxicity of methanol extract of C. pectinata was determined by the OECD (2002) guidelines No. 423 method [77]. Mice were divided into six groups, where each group contained five animals. The first group received 1\% Tween- 80 in normal saline. The other groups were received 400 , $600,800,1000,2000 \mathrm{mg} / \mathrm{kg}$ of MECP dose. Then all the animals were observed for $8 \mathrm{~h}$ to detect early symptoms such as behavioral changes or mortality, morbidity and later for 3 days. 


\subsection{Phytochemical Screening}

In the preliminary phytochemical screening of freshly prepared methanol leaves crude extract was qualitatively tested for the determination of carbohydrates, alkaloids, glycosides, tannins, terpenoids, flavonoids, and saponins [78,79].

\subsection{Antidepressant Activity}

\subsubsection{Experimental Design for Anti-Depressant Activity}

The antidepressant activity of the extract eValuated by the tail suspension test and forced swimming test. The mice were divided into four groups $(n=5)$. Administration of extract/control to the animals was followed after 60 min prior to study [80,81]:

Group I: Negative control received 1\% Tween-80 (10 mL/kg, b.w.) orally

Group II: Positive control phenelzine received $20 \mathrm{mg} / \mathrm{kg}$ b.w. I.P.

Group III: Positive control fluoxetine received $10 \mathrm{mg} / \mathrm{kg}$ b.w. I.P.

Group IV: Received MECP 200 mg/kg b.w. orally

Group V: Received MECP $400 \mathrm{mg} / \mathrm{kg}$ b.w. orally

\subsubsection{Tail Suspension Test (TST)}

The antidepressant activity of MECP was executed by the method described by Steru et al. [80]. The treatment was followed as described in Section 3.7.1. After $60 \mathrm{~min}$ of treatment, each mouse was suspended by using adhesive tape at the tip of the tail over the rim of a box. Then the immobility time was recorded from the 6 min suspended period, whereas the first 2 min for initial adjustment and last 4 min for immobility time:

$$
\text { Inhibition }(\%)=\frac{\mathrm{A}-\mathrm{B}}{\mathrm{A}} \times 100
$$

where, $\mathrm{A}=$ immobile time in the control group; $\mathrm{B}=$ immobile time in the test group.

\subsubsection{Forced Swimming Test (FST)}

The antidepressant activity of MECP was eValuated by the forced swimming test, as described by Porsolt et al., [81]. A glass box $\left(25 \times 15 \times 25 \mathrm{~cm}^{3}\right)$ filled to $15 \mathrm{~cm}$ with water $\left(25 \pm 2{ }^{\circ} \mathrm{C}\right)$ was utilized as a test apparatus for swimming. The treatment was followed as described in Section 3.7.1. After $60 \mathrm{~min}$ of treatment, each mouse was forced to swim in the apparatus. The immobility time was calculated from the 6 min swimming period. When the mice stopped struggling and remained suspended in water was considered as the immobility time and the period is recorded.

$$
\text { Inhibition }(\%)=\frac{\mathrm{A}-\mathrm{B}}{\mathrm{A}} \times 100
$$

where, $\mathrm{A}=$ immobile time in the control group; $\mathrm{B}=$ immobile time in the test group.

\subsection{Brine Shrimp Lethality Bioassay}

The brine shrimp lethality bioassay was followed to eValuate the cytotoxicity of methanol extract of C. pectinata leaves by Meyer et al. [39]. In $1000 \mathrm{~mL}$ distilled water, $38 \mathrm{~g} \mathrm{NaCl}$ was dissolved to prepare artificial seawater. $\mathrm{NaOH}$ was added to maintain the $\mathrm{pH}$ at 8.0. Then serially diluted concentrations of $50,100,200,400,600$ and $800 \mu \mathrm{g} / \mathrm{mL}$ were obtained. Vincristine sulfate used as a positive control as the preceding method in a serial concentration dilution $0.125,0.25,0.5,1,5$ and $10 \mu \mathrm{g} / \mathrm{mL}$. Then ten matured live shrimp were placed in all test tubes at room temperature $\left(25 \pm 1{ }^{\circ} \mathrm{C}\right)$ and after $24 \mathrm{~h}$, each test tube was assessed, and the number of alive nauplii was counted and recorded.

$$
\% \text { of viability }=\left(\mathrm{N}_{1} / \mathrm{N}_{0}\right) \times 100
$$


where, $\mathrm{N}_{0}=$ Number of nauplii taken; $\mathrm{N}_{1}=$ Number of nauplii alive

\subsection{In Silico Study}

\subsubsection{Quantum Chemical Analysis}

Quantum chemical analysis was performed with the Gaussian 09 software package [82] via the Gauss view 6.0.10 [83] molecular visualization program on a Pentium IV/3.02Hz personal computer. The selected isolated compounds 5-chloro-1-(trimethylsilyl)- $1 \mathrm{H}$-indole-2,3-dione 3-[O-(trimethylsilyl) oxime], cyclopentadecanone oxime and trans-2-dodecen-1-ol trifluoroacetate were fully optimized at the level of density functional theory (DFT) using the B3LYP with the 6-31G+ $(d, p)$ basis set. The minima of the potential energy hypersurfaces were considered to be the stationary points and confirmed from the absence of any imaginary frequency. Electronic properties, such as HOMO-LUMO energies, molecular electrostatic potential (MESP) were calculated using the B3LYP method, based on the optimized structure in the gas phase. Furthermore, Mulliken and natural bond orbital (NBO) charges and global reactivity descriptors of the proposed compounds were analyzed. Calculated vibrational frequencies were multiplied by a suiTable scaling number (0.964) [84] to better match experimental frequencies. Besides, the ${ }^{1} \mathrm{H}$ and ${ }^{13} \mathrm{C}$ nuclear magnetic resonance (NMR) chemical shift [85] (with respect to a TMS reference and chloroform solution) of the proposed compounds were also carried out by GIAO method in same method and level of basis set.

\subsubsection{Molecular Docking Study}

The optimized structure of 5-chloro-1-(trimethylsilyl)-1H-indole-2,3-dione 3-[O-(trimethylsilyl) oxime], cyclopentadecanone oxime; and trans-2-dodecen-1-ol trifluoroacetate were subjected to a molecular docking study according to Sastry et al. as briefly explained in Adnan et al. [86,87]. The proteins used for the docking study were retrieved from the Protein data bank (https://www. rcsb.org/structure/): human monoamine oxidase A (PDB ID: 2Z5X), human serotonin (PDB ID: 5I6X), human estrogen receptor (PDB ID: 1ERR), and epidermal growth factor receptor tyrosine kinase (PDB ID: 1M17) [88]. The molecular docking study was performed using Schrödinger (Maestro v11.1).

\subsubsection{ADME/T and Toxicological Properties Analysis}

The optimized structures of 5-chloro-1-(trimethylsilyl)-1H-Indole-2,3-dione 3-[O-(trimethylsilyl) oxime], cyclopentadecanone oxime and trans-2-dodecen-1-ol trifluoroacetate were subjected to ADME/T following the rules of Lipinski (Rule of Five) [74] and Veber [75]. In addition, the toxicological properties were analyzed by the admetSAR (http://lmmd.ecust.edu.cn/admetsar2/). The ADME/T analysis was eValuated by SwissADME (http://www.swissadme.ch/) [89].

\subsection{Statistical Analysis}

The values are shown as mean \pm standard error mean (SEM). ${ }^{*} p<0.001$ statistical significance was calculated by one-way ANOVA (Dunnett's test) using the GraphPad Prism (version 8.4.) software (San Diego, CA, USA).

\section{Conclusions}

This study reports that methanol leaves extract of $C$. pectinata could be a potential source of compounds with antidepressant and cytotoxicity activity due to the presence of secondary metabolites. In addition, the computational study of the oxime derivatives by DFT and molecular docking study unveiled better binding interaction against the MAO and serotonin receptor with good pharmacokinetic and toxicological properties. Further advanced studies are recommended to identify the mechanism of action of C. pectinata. 
Supplementary Materials: The following are available online at http://www.mdpi.com/1424-8247/13/9/232/s1, Table S1: Mulliken atomic charges and NBO charges at different atoms in gas phase of 5-chloro-1-(trimethylsilyl)1H-indole-2,3-dione 3-[O-(trimethylsilyl)-oxime] computed by B3LYP/methods with 6-31G+ $(\mathrm{d}, \mathrm{p})$ basis set. Table S2: Mulliken atomic charges and NBO charges at different atoms in gas phase of cyclopentadecanone oxime computed by B3LYP/methods with 6-31G+ $(\mathrm{d}, \mathrm{p})$ basis set. Table S3: Mulliken atomic charges and NBO charges at different atoms in gas phase of trans-2-dodecen-1-ol trifluoroacetate computed by B3LYP/methods with 6-31G+ $(\mathrm{d}, \mathrm{p})$ basis set. Figure S1: Total ionic chromatogram (TIC) of MECP by GC-MS. Figure S2: Fourier transform Infrared- (FT-IR) spectrum of 5-chloro-1-(trimethylsilyl)-1H-indole-2,3-dione 3-[O-(trimethylsilyl)-oxime] (A); cyclopentadecanone oxime (B); trans-2-dodecen-1-ol trifluoroacetate (C), respectively in the wavenumber range $4000-0 \mathrm{~cm}-1$. Figure S3: Calculated 1H-NMR isotropic chemical shift spectrum of 5-chloro-1-(trimethylsilyl)-1H-indole-2,3-dione 3-[O-(trimethylsilyl)-oxime] (A); cyclopentadecanone oxime (B); trans-2-dodecen-1-ol trifluoroacetate (C), respectively in chloroform solvent. Figure S4: Calculated 13C NMR isotropic chemical shift spectrum of 5-chloro-1-(trimethylsilyl)-1H-indole-2,3-dione 3-[O-(trimethylsilyl)-oxime] (A); cyclopentadecanone oxime (B); trans-2-dodecen-1-ol trifluoroacetate (C), respectively in chloroform solvent. Figure S5: 3D and 2D interactions of cyclopentadecanone oxime (A); trans-2-dodecen-1-ol trifluoroacetate (B); phenelzine (C), against the human monoamine oxidase A (PDB: 2Z5X) for antidepressant activity; Figure S6: 3D and 2D interactions of cyclopentadecanone oxime (A); trans-2-dodecen-1-ol trifluoroacetate (B); fluoxetine $(\mathrm{C})$, against the human serotonin receptor (PDB: 5I6X) for antidepressant activity; Figure S7: 3D and 2D interactions of cyclopentadecanone oxime (A); trans-2-dodecen-1-ol trifluoroacetate (B); vincristine sulfate $(C)$, against the human estrogen receptor (PDB ID: 1ERR) for cytotoxicity activity; Figure S8: $3 \mathrm{D}$ and 2D interactions of cyclopentadecanone oxime (A); trans-2-dodecen-1-ol trifluoroacetate (B); vincristine sulfate (C), against the epidermal growth factor receptor tyrosine kinase (PDB ID: 1M17) for cytotoxicity activity.

Author Contributions: J.R., and A.M.T.; conceptualization, planning, designing, investigation, data analysis, software, manuscript writing, M.M.H.; designing, manuscript writing, data analysis, S.A.S.; planning, designing, investigation, data analysis, DFT calculation, M.N.I.; designing, investigation, data analysis, A.B.M.N.U., M.H.; and M.S.N. data curation, data analysis, in silico investigation, A.S.M.A.R., T.B.E., M.H.A., and J.S.-G.; monitoring, visualization, supervision, A.S.M.A.R., R.C. and J.S.-G., together with writing-review \& editing, correspondence. All authors have read and agreed to the published version of the manuscript.

Funding: This research was supported by the Center for Research and Publication (CRP) grant (IRG 180111), International Islamic University Chittagong (IIUC).

Acknowledgments: This research was supported by the Department of Pharmacy, International Islamic University Chittagong-4318, Bangladesh. The authors also express gratitude to Department of Theoretical and Computational Chemistry, University of Dhaka, Dhaka-1000, Bangladesh for logistics support and providing the Gaussian 09 software package.

Conflicts of Interest: The authors declare no conflict of interest.

\section{Abbreviations}

$\begin{array}{ll}\text { MECP } & \text { methanol extract of } C \text {. pectinata leaves } \\ \text { GC-MS } & \text { Gas Chromatography-Mass Spectroscopy } \\ \text { IP } & \text { intraperitoneal } \\ \text { b.w. } & \text { body weight } \\ \text { MAO } & \text { monoamine oxidase } \\ \text { NMR } & \text { nuclear magnetic resonance } \\ \text { DFT } & \text { density functional theory } \\ \text { ADME/T } & \text { absorption, distribution, metabolism, excretion, and toxicity } \\ \text { PDB } & \text { protein data bank } \\ \text { SEM } & \text { standard error mean } \\ \text { ANOVA } & \text { one-way analysis of variance } \\ \text { FMOs } & \text { frontier molecular orbitals } \\ \text { HOMO } & \text { highest occupied molecular orbital } \\ \text { LUMO } & \text { lowest unoccupied molecular orbital } \\ \text { MESP } & \text { molecular electrostatic potential } \\ \text { NBO } & \text { natural bond orbital }\end{array}$

\section{References}

1. Rosenbaum, D.; Hagen, K.; Deppermann, S.; Kroczek, A.M.; Haeussinger, F.B.; Heinzel, S.; Berg, D.; Fallgatter, A.J.; Metzger, F.G.; Ehlis, A.-C. State-dependent altered connectivity in late-life depression: A functional near-infrared spectroscopy study. Neurobiol. Aging 2016, 39, 57-68. [CrossRef] [PubMed] 
2. Calvó-Perxas, L.; Vilalta-Franch, J.; Turró-Garriga, O.; López-Pousa, S.; Garre-Olmo, J. Gender differences in depression and pain: A two year follow-up study of the Survey of Health, Ageing and Retirement in Europe. J. Affect. Disord. 2016, 193, 157-164. [CrossRef] [PubMed]

3. Gadassi, R.; Mor, N. Confusing acceptance and mere politeness: Depression and sensitivity to Duchenne smiles. J. Behav. Ther. Exp. Psychiatry 2016, 50, 8-14. [CrossRef] [PubMed]

4. Ridout, K.K.; Ridout, S.J.; Price, L.H.; Sen, S.; Tyrka, A.R. Depression and telomere length: A meta-analysis. J. Affect. Disord. 2016, 191, 237-247. [CrossRef] [PubMed]

5. Perviz, S.; Khan, H.; Pervaiz, A. Plant Alkaloids as an Emerging Therapeutic Alternative for the Treatment of Depression. Front. Pharmacol. 2016, 7, 28. [CrossRef]

6. Gold, P.W.; Goodwin, F.K.; Chrousos, G.P. Clinical and Biochemical Manifestations of Depression. N. Engl. J. Med. 1988, 319, 413-420. [CrossRef]

7. Tondo, L.; Isacsson, G.; Baldessarini, R.J. Suicidal behaviour in bipolar disorder: Risk and prevention. CNS Drugs 2003, 17, 491-511. [CrossRef]

8. Alexander, R.C.; Preskorn, S. Clinical pharmacology in the development of new antidepressants: The challenges. Curr. Opin. Pharmacol. 2014, 14, 6-10. [CrossRef]

9. García-Ríos, R.I.; Mora-Pérez, A.; Ramos-Molina, A.R.; Soria-Fregozo, C. Neuropharmacology of Secondary Metabolites from Plants with Anxiolytic and Antidepressant Properties. In Behavioral Pharmacology-From Basic to Clinical Research; IntechOpen: London, UK, 2020.

10. Sørensen, M.; Neilson, E.H.J.; Møller, B.L. Oximes: Unrecognized Chameleons in General and Specialized Plant Metabolism. Mol. Plant 2018, 11, 95-117. [CrossRef]

11. Hertiani, T.; Edrada-Ebel, R.; Ortlepp, S.; van Soest, R.W.M.; de Voogd, N.J.; Wray, V.; Hentschel, U.; Kozytska, S.; Müller, W.E.G.; Proksch, P. From anti-fouling to biofilm inhibition: New cytotoxic secondary metabolites from two Indonesian Agelas sponges. Bioorg. Med. Chem. 2010, 18, 1297-1311. [CrossRef]

12. Wei, K.; Wang, G.-Q.; Bai, X.; Niu, Y.-F.; Chen, H.-P.; Wen, C.-N.; Li, Z.-H.; Dong, Z.-J.; Zuo, Z.-L.; Xiong, W.-Y.; et al. Structure-Based Optimization and Biological eValuation of Pancreatic Lipase Inhibitors as Novel Potential Antiobesity Agents. Nat. Prod. Bioprospect. 2015, 5, 129-157. [CrossRef] [PubMed]

13. Karakurt, A.; Dalkara, S.; Özalp, M.; Özbey, S.; Kendi, E.; Stables, J.P. Synthesis of some 1-(2-naphthyl)-2-(imidazole-1-yl) ethanone oxime and oxime ether derivatives and their anticonvulsant and antimicrobial activities. Eur. J. Med. Chem. 2001, 36, 421-433. [CrossRef]

14. Schenone, S.; Bruno, O.; Ranise, A.; Bondavalli, F.; Filippelli, W.; Falcone, G.; Rinaldi, B. O-[2-Hydroxy-3-(dialkylamino) propyl]ethers of (+)-1,7,7-trimethyl bicyclo[2.2.1]heptan-2-one oxime (camphor oxime) with analgesic and antiarrhythmic activities. IL Farmaco 2000, 55, 495-498. [CrossRef]

15. Sivaraman, D.; Vignesh, G.; Selvaraj, R.; Dare, B.J. Identification of potential monoamine oxidase inhibitor from herbal source for the treatment of major depressive disorder: An in-silico screening approach. Der. Pharma. Chem. 2015, 7, 224-234.

16. Rudorfer, M.V.; Potter, W.Z. Antidepressants. Drugs 1989, 37, 713-738. [CrossRef]

17. Bozdağ, O.; Gümüşel, B.; Demirdamar, R.; Büyükbingöl, E.; Rolland, Y.; Ertan, R. Synthesis of some novel oxime ether derivatives and their activity in the 'behavioral despair test'. Eur. J. Med. Chem. 1998, 33, 133-141. [CrossRef]

18. Davrinche, C.; Nguyen-Tri-Xuong, E.; El Hamad, Y.; Reynaud, P.; Rinjard, P.; Tran, G. Amide-oximes et hydroximates benzodioxaniques: Synthèse de nouveaux composés et étude en neuropsycho-pharmacologie. Eur. J. Med. Chem. 1992, 27, 765-778. [CrossRef]

19. Ertan, R.; BozdaĞ, O.Y.A.; KesİCİ, B.; Palaska, E.; Ertan, M. Studies on the synthesis and antidepressant activity of some new oxime-ether derivatives. Acta Pharm. Sci. 1998, 40, 131-135.

20. Oh, J.M.; Rangarajan, T.M.; Chaudhary, R.; Singh, R.P.; Singh, M.; Singh, R.P.; Tondo, A.R.; Gambacorta, N.; Nicolotti, O.; Mathew, B. Novel Class of Chalcone Oxime Ethers as Potent Monoamine Oxidase-B and Acetylcholinesterase Inhibitors. Molecules 2020, 25, 2356. [CrossRef]

21. Islam, M.; Rahman, M.; Hossain, G. Floristic composition and phytodiversity status of Sitakunda Ecopark, Chittagong, Bangladesh. Jahangirnagar Univ. J. Biol. Sci. 2016, 5, 29. [CrossRef]

22. Rakib, A.; Ahmed, S.; Islam, M.A.; Uddin, M.M.N.; Paul, A.; Chy, M.N.U.; Emran, T.B.; Seidel, V. Pharmacological studies on the antinociceptive, anxiolytic and antidepressant activity of Tinospora crispa. Phytotherapy Res. 2020. [CrossRef] [PubMed] 
23. Tareq, A.M.; Farhad, S.; Neshar Uddin, A.B.M.; Hoque, M.; Nasrin, M.S.; Uddin, M.M.R.; Hasan, M.; Sultana, A.; Munira, M.S.; Lyzu, C.; et al. Chemical profiles, pharmacological properties, and in silico studies provide new insights on Cycas Pectinata. Heliyon 2020, 6, e04061. [CrossRef] [PubMed]

24. Moawad, A.; Hetta, M.; Zjawiony, J.K.; Jacob, M.R.; Hifnawy, M.; Marais, J.P.J.; Ferreira, D. Phytochemical investigation of Cycas circinalis and Cycas revoluta leaflets: Moderately active antibacterial biflavonoids. Planta Med. 2010, 76, 796-802. [CrossRef] [PubMed]

25. Nair, J.J.; van Staden, J. Isolation and quantification of the toxic methylazoxymethanol glycoside macrozamin in selected South African cycad species. S. Afr. J. Bot. 2012, 82, 108-112. [CrossRef]

26. Negm, W.; Ibrahim, A.R.; Aboelsauod, K.; Ragab, A.; Attia, G.I. GC-MS Analysis of Petroleum Ether Extract and Volatiles of Cycas revoluta Thunb Growing in Egypt. Inventi Rapid Planta Act. 2016, 2016, 1-5.

27. Kumar, S.B.; Kumar, V.J. GC-MS Analysis of Bioactive Constituents from Cycas circinalis L. and Ionidium suffruticosum Ging. Int. J. Pharm. Sci. Rev. Res. 2014, 28, 197-201.

28. Ben, I.O.; Woode, E.; Abotsi, W.K.M.; Boakye-Gyasi, E. Preliminary phytochemical screening and in vitro antioxidant prop-erties of Trichilia monadelpha (Thonn.) JJ De Wilde (Meliaceae). J. Med. Biomed. Sci. 2013, 2, 6-15.

29. Bell, W.R. eValuation of Thrombolytic Agents. Drugs 1997, 54, 11-17. [CrossRef]

30. Schenone, S.; Bruno, O.; Ranise, A.; Bondavalli, F.; Filippelli, W.; Falcone, G.; Rinaldi, B. Treating Depression and Anxiety in Primary Care. Prim. Care Companion J. Clin. Psychiatry 2008, 10, 145-152. [CrossRef]

31. Adnan, M.; Chy, M.N.; Kamal, A.T.M.M.; Chowdhury, K.A.; Rahman, M.A.; Reza, A.S.M.A.; Moniruzzaman, M.; Rony, S.R.; Nasrin, M.S.; Azad, M.O.; et al. Intervention in Neuropsychiatric Disorders by Suppressing Inflammatory and Oxidative Stress Signal and Exploration of In Silico Studies for Potential Lead Compounds from Holigarna caustica (Dennst.) Oken leaves. Biomolecules 2020, 10, 561. [CrossRef]

32. Benneh, C.K.; Biney, R.P.; Adongo, D.W.; Mante, P.K.; Ampadu, F.A.; Tandoh, A.; Jato, J.; Woode, E. Anxiolytic and Antidepressant Effects of Maerua angolensis DC. Stem Bark Extract in Mice. Depress. Res. Treat. 2018, 2018, 1537371. [CrossRef] [PubMed]

33. Beheshti, F.; Khazaei, M.; Hosseini, M. Neuropharmacological effects of Nigella sativa. Avicenna J. Phytomed. 2016, 6, 104-116. [PubMed]

34. Baldwin, D.S.; Polkinghorn, C. eVidence-based pharmacotherapy of Generalized Anxiety Disorder. Int. J. Neuropsychopharmacol. 2005, 8, 293-302. [CrossRef]

35. Cryan, J.F.; Mombereau, C.; Vassout, A. The tail suspension test as a model for assessing antidepressant activity: Review of pharmacological and genetic studies in mice. Neurosci. Biobehav. Rev. 2005, 29, 571-625. [CrossRef] [PubMed]

36. El Refaey, H. Fluoxetine. In xPharm: The Comprehensive Pharmacology Reference; Elsevier: Amsterdam, The Netherlands, 2007; pp. 1-9. [CrossRef]

37. Brigitta, B. Pathophysiology of depression and mechanisms of treatment. Dialogues Clin. Neurosci. 2002, 4, 7-20.

38. Abdulrasheed, M.; Ibrahim, I.H.; Mubarak, M.A.; Umar, F.A. Comparison of antimicrobial activity of seed oil of garlic and Moringa oleifera against some food-borne microorganisms. Bayero J. Pure Appl. Sci. 2015, 8, 196-201. [CrossRef]

39. Meyer, B.N.; Ferrigni, N.R.; Putnam, J.E.; Jacobsen, L.B.; Nichols, D.E.J.; McLaughlin, J.L. Brine shrimp: A convenient general bioassay for active plant constituents. Planta Med. 1982, 45, 31-34. [CrossRef]

40. Parvez, M.; Mosaddik, A. eValuation of Brine Shrimp Cytotoxicity of Mango Peel and Flesh after Formalin Treatment. Int. J. Innov. Pharm. Sci. Res. 2016, 4, 900-908. [CrossRef]

41. Soga, S.; Sharma, S.V.; Shiotsu, Y.; Shimizu, M.; Tahara, H.; Yamaguchi, K.; Ikuina, Y.; Murakata, C.; Tamaoki, T.; Kurebayashi, J.; et al. Stereospecific antitumor activity of radicicol oxime derivatives. Cancer Chemoth. Pharm. 2001, 48, 435-445. [CrossRef]

42. Minkin, V.I.; Osipov, O.A.; Zhdanov, Y.A. Dipole Moments in Organic Chemistry; Springer: Berlin/Heidelberg, Germany, 2012. [CrossRef]

43. Baldin, A.M. Polarizability of nucleons. Nucl. Phys. 1960, 18, 310-317. [CrossRef]

44. Gómez-Jeria, J.S. An empirical way to correct some drawbacks of mulliken population analysis. J. Chil. Chem. Soc. 2009, 54, 482-485. [CrossRef]

45. Reed, A.E.; Weinstock, R.B.; Weinhold, F. Natural population analysis. J. Chem. Phys. 1985, 83, 735-746. [CrossRef] 
46. Sheikhi, M.; Sheikh, D. Quantum chemical investigations on phenyl-7, 8-dihydro-[1,3]-dioxolo [4,5-g] quinolin-6 (5h)-one. Rev. Roum. Chim. 2014, 59, 761-767.

47. Choi, C.H.; Kertesz, M. Bond length alternation and aromaticity in large annulenes. J. Chem. Phys. 1998, 108, 6681-6688. [CrossRef]

48. Fleming, I. Frontier Orbitals and Organic Chemical Reactions; Wiley: Hoboken, NJ, USA, 1977.

49. Koopmans, T. Ordering of wave functions and eigenenergies to the individual electrons of an atom. Physica 1933, 1, 104-113. [CrossRef]

50. Phillips, J.C. Generalized Koopmans' Theorem. Phys. Rev. 1961, 123, 420-424. [CrossRef]

51. Flippin, L.A.; Gallagher, D.W.; Jalali-Araghi, K. A convenient method for the reduction of ozonides to alcohols with borane-dimethyl sulfide complex. J. Org. Chem. 1989, 54, 1430-1432. [CrossRef]

52. Parr, R.G.; Szentpály, L.v.; Liu, S. Electrophilicity Index. J. Am. Chem. Soc. 1999, 121, 1922-1924. [CrossRef]

53. Chattaraj, P.K.; Giri, S. Stability, Reactivity, and Aromaticity of Compounds of a Multivalent Superatom. J. Phys. Chem. A 2007, 111, 11116-11121. [CrossRef]

54. Padmanabhan, J.; Parthasarathi, R.; Subramanian, V.; Chattaraj, P.K. Electrophilicity-Based Charge Transfer Descriptor. J. Phys. Chem. A 2007, 111, 1358-1361. [CrossRef]

55. Ayers, P.W.; Parr, R.G. Variational Principles for Describing Chemical Reactions: The Fukui Function and Chemical Hardness Revisited. J. Am. Chem. Soc. 2000, 122, 2010-2018. [CrossRef]

56. Obi-Egbedi, N.O.; Obot, I.B.; El-Khaiary, M.I.; Umoren, S.A.; Ebenso, E.E. Computational simulation and statistical analysis on the relationship between corrosion inhibition efficiency and molecular structure of some phenanthroline derivatives on mild steel surface. Int. J. Electrochem. Sci. 2011, 6, e5675.

57. Parr, R.G.; Donnelly, R.A.; Levy, M.; Palke, W.E. Electronegativity: The density functional viewpoint. J. Chem. Phys. 1978, 68, 3801-3807. [CrossRef]

58. Pulay, P.; Fogarasi, G.; Pang, F.; Boggs, J.E. Systematic ab initio gradient calculation of molecular geometries, force constants, and dipole moment derivatives. J. Am. Chem. Soc. 1979, 101, 2550-2560. [CrossRef]

59. Rauhut, G.; Pulay, P. Transferable Scaling Factors for Density Functional Derived Vibrational Force Fields. J. Phys. Chem. 1995, 99, 3093-3100. [CrossRef]

60. Rajesh, P.; Gunasekaran, S.; Gnanasambandan, T.; Seshadri, S. Experimental and theoretical study of ornidazole. Spectrochim. Acta A Mol. Biomol. Spectrosc. 2016, 153, 496-504. [CrossRef]

61. Lampert, H.; Mikenda, W.; Karpfen, A. Molecular Geometries and Vibrational Spectra of Phenol, Benzaldehyde, and Salicylaldehyde: Experimental versus Quantum Chemical Data. J. Phys. Chem. A 1997, 101, 2254-2263. [CrossRef]

62. Puviarasan, N.; Arjunan, V.; Mohan, S. FT-IR and FT-Raman studies on 3-aminophthalhydrazide and $\mathrm{N}$-aminophthalimide. Turk. J. Chem. 2002, 26, 323-334.

63. Govindarajan, M.; Ganasan, K.; Periandy, S.; Karabacak, M. Experimental (FT-IR and FT-Raman), electronic structure and DFT studies on 1-methoxynaphthalene. Spectrochim. Acta A Mol. Biomol. Spectrosc. 2011, 79, 646-653. [CrossRef]

64. Colthup, N. Introduction to Infrared and Raman Spectroscopy; Elsevier: Amsterdam, The Netherlands, 2012.

65. Roeges, N.P.G.; Baas, J.M.A. A Guide to the Complete Interpretation of Infrared Spectra of Organic Structures; Wiley: New York, NY, USA, 1994.

66. Laszlo, V.; Endre, K.; Jozsef, B.; Boris, D.; Antal, S. Diethylamino and Pyrrolidino Lower Alkyl Esters of 3,5-dimethoxy-4-butoxy and Amyloxy Benzoic Acids. US3228961A, 11 January 1966.

67. Silverstein, R.; Bassler, G.; Morrill, T. Spectrometric Identification of Organic Compounds; John Wiley and Sons: New York, NY, USA, 1981.

68. Krishnakumar, V.; Manohar, S.; Nagalakshmi, R. Crystal growth and characterization of N-hydroxyphthalimide $\left(\mathrm{C}_{8} \mathrm{H}_{5} \mathrm{NO}_{3}\right)$ crystal. Spectrochim. Acta A Mol. Biomol. Spectrosc. 2008, 71, 110-115. [CrossRef]

69. Smith, B.C. Infrared Spectral Interpretation: A Systematic Approach; CRC Press: Boca Raton, FL, USA, 1998. [CrossRef]

70. Abbas, A.; Gökce, H.; Bahçeli, S. Spectroscopic (vibrational, NMR and UV-vis.) and quantum chemical investigations on 4-hexyloxy-3-methoxybenzaldehyde. Spectrochim. Acta A Mol. Biomol. Spectrosc. 2016, 152, 596-607. [CrossRef] [PubMed] 
71. Baig, M.H.; Ahmad, K.; Roy, S.; Ashraf, J.M.; Adil, M.; Siddiqui, M.H.; Khan, S.; Kamal, M.A.; Provazník, I.; Choi, I. Computer Aided Drug Design: Success and Limitations. Curr. Pharm. Des. 2016, 22, 572-581. [CrossRef] [PubMed]

72. Youdim, M.B.; Edmondson, D.; Tipton, K.F. The therapeutic potential of monoamine oxidase inhibitors. Nat. Rev. Neurosci. 2006, 7, 295-309. [CrossRef] [PubMed]

73. Lin, J.; Sahakian, D.C.; de Morais, S.M.; Xu, J.J.; Polzer, R.J.; Winter, S.M. The role of absorption, distribution, metabolism, excretion and toxicity in drug discovery. Curr. Top. Med. Chem. 2003, 3, 1125-1154. [CrossRef] [PubMed]

74. Lipinski, C.A.; Lombardo, F.; Dominy, B.W.; Feeney, P.J. Experimental and computational approaches to estimate solubility and permeability in drug discovery and development settings. Adv. Drug Deliv. Rev. 1997, 23, 3-25. [CrossRef]

75. Veber, D.F.; Johnson, S.R.; Cheng, H.-Y.; Smith, B.R.; Ward, K.W.; Kopple, K.D. Molecular Properties That Influence the Oral Bioavailability of Drug Candidates. J. Med. Chem. 2002, 45, 2615-2623. [CrossRef]

76. Zimmermann, M. Ethical guidelines for investigations of experimental pain in conscious animals. Pain 1983, 16, 109-110. [CrossRef]

77. Mielke, H.; Strickland, J.; Jacobs, M.N.; Mehta, J.M. Biometrical eValuation of the performance of the revised OECD Test Guideline 402 for assessing acute dermal toxicity. Regul. Toxicol. Pharmacol. 2017, 89, 26-39. [CrossRef]

78. Hossain, M.S.; Reza, A.; Rahaman, M.M.; Nasrin, M.S.; Rahat, M.R.U.; Islam, M.R.; Uddin, M.J.; Rahman, M.A. eValuation of morning glory (Jacquemontia tamnifolia (L.) Griseb) leaves for antioxidant, antinociceptive, anticoagulant and cytotoxic activities. J. Basic Clin. Physiol. Pharmacol. 2018, 29, 291-299. [CrossRef]

79. Evans, W.C. Trease and eVans Pharmacognosy, International Edition E-Book; Elsevier: Amsterdam, The Netherlands, 2009.

80. Steru, L.; Chermat, R.; Thierry, B.; Simon, P. The tail suspension test: A new method for screening antidepressants in mice. Psychopharmacology 1985, 85, 367-370. [CrossRef]

81. Porsolt, R.D.; Bertin, A.; Jalfre, M. Behavioral despair in mice: A primary screening test for antidepressants. Arch. Int. Pharmacodyn. Ther. 1977, 229, 327-336. [PubMed]

82. Frisch, M.; Trucks, G.; Schlegel, H.B.; Scuseria, G.E.; Robb, M.A.; Cheeseman, J.R.; Scalmani, G.; Barone, V.; Mennucci, B.; Petersson, G.; et al. Gaussian 09; Revision d. 01; Gaussian Inc.: Wallingford CT, USA, 2009; p. 201.

83. Dennington, R.; Keith, T.A.; Millam, J.M. GaussView, Version 6.0; Semichem Inc.: Shawnee, KS, USA, 2016 ; p. 16.

84. Fekete, Z.A.; Hoffmann, E.A.; Körtvélyesi, T.; Penke, B. Harmonic vibrational frequency scaling factors for the new NDDO Hamiltonians: RM1 and PM6. Mol. Phys. 2007, 105, 2597-2605. [CrossRef]

85. Ramazani, A.; Sheikhi, M.; Yahyaei, H. Molecular Structure, NMR, FMO, MEP and NBO Analysis of Ethyl-(Z)-3-phenyl-2-(5-phenyl-2H-1,2,3,4-tetraazol-2-yl)-2-propenoate Based on HF and DFT Calculations. Chem. Methodol. 2017, 1, 28-48. [CrossRef]

86. Sastry, G.M.; Adzhigirey, M.; Day, T.; Annabhimoju, R.; Sherman, W. Protein and ligand preparation: Parameters, protocols, and influence on virtual screening enrichments. J. Comput. Aided Mol. Des. 2013, 27, 221-234. [CrossRef]

87. Adnan, M.; Chy, M.N.; Kamal, A.T.M.M.; Chowdhury, M.R.; Islam, M.S.; Hossain, M.A.; Tareq, A.M.; Bhuiyan, M.I.; Uddin, M.N.; Tahamina, A.; et al. Unveiling Pharmacological Responses and Potential Targets Insights of Identified Bioactive Constituents of Cuscuta reflexa Roxb. Leaves through In Vivo and In Silico Approaches. Pharmaceuticals 2020, 13, 50. [CrossRef]

88. Berman, H.M.; Battistuz, T.; Bhat, T.N.; Bluhm, W.F.; Bourne, P.E.; Burkhardt, K.; Feng, Z.; Gilliland, G.L.; Iype, L.; Jain, S.; et al. The Protein Data Bank. Acta Crystallogr. Sect. D Biol. Crystallogr. 2002, 58, 899-907. [CrossRef]

89. Natarajan, A.; Sugumar, S.; Bitragunta, S.; Balasubramanyan, N. Molecular docking studies of $(4 Z, 12 Z)$-cyclopentadeca-4, 12-dienone from Grewia hirsuta with some targets related to type 2 diabetes. BMC Complement. Altern. Med. 2015, 15, 73. [CrossRef]

(C) 2020 by the authors. Licensee MDPI, Basel, Switzerland. This article is an open access article distributed under the terms and conditions of the Creative Commons Attribution (CC BY) license (http://creativecommons.org/licenses/by/4.0/). 